\title{
APROXIMACIÓN A UNA TEORÍA DE LOS "ACTOS CONSTITUCIONALES»
}

\author{
ANTONIO M. GARCÍA CUADRADO \\ Profesor Titular de Derecho Constitucional \\ Universidad de Alicante
}




\section{SUMARIO}

I. Planteamiento. II. El concepto de "acto constitucional». 1. Aproximación a la idea. 2. Definición de acto constitucional. 3. Actos constitucionales $y$ actos políticos. III. Clasificación DE LOS Actos constitucionales. 1. Según su autor. 2. Según su contenido. 3. Según su eficacia. 4. Según su forma. 5. Según su naturaleza. IV. EL CONTROL JURISDICCIONAL DE LOS ACTOS CONSTITUCIONALES. 1. ¿Control de legalidad o control de constitucionalidad? 2. Fiscalización por los tribunales contencioso-administrativos. 3. Fiscalización por el Tribunal Constitucional. V. Actos constitucionales Y ACtOS CON FUERZA DE LEY. 1. Qué son los "actos con fuerza de ley". 2. Los actos constitucionales son los actos con fuerza de ley. VI. Conclusiones. 


\title{
APROXIMACIÓN A UNA TEORÍA DE LOS «ACTOS CONSTITUCIONALES»
}

\author{
POR \\ ANTONIO M. GARCÍA CUADRADO \\ Profesor Titular de Derecho Constitucional \\ Universidad de Alicante
}

\section{PLANTEAMIENTO}

El objeto del presente trabajo es presentar las lineas fundamentales de una categoría de actos jurídico-públicos descuidada indebidamente por la doctrina a los que, por las razones que más adelante se exponen, denominaré «actos constitucionales». No es pués mi intención tratar aquí con detenimiento todos y cada uno de los problemas jurídico-constitucionales y jurídico-procesales que implican las afirmaciones que se hacen a continuación; se trata simplemente de definir un tipo de actos presentando las ideas básicas de las que puedan extraerse las respuestas a las innumerables cuestiones que de ahi surjan.

Partimos de la base de que el carácter plenamente normativo de nuestra Constitución no es ya una doctrina sino un hecho cierto avalado por infinidad de casos planteados ante y resueltos por los mismos órganos jurisdiccionales ordinarios. A estas alturas no hace falta detenerse a demostrar tales exigencias del moderno Estado de Derecho. A mi juicio, sin embargo no se han extraído del principio todas las consecuencias jurídicas que inevitablemente conlleva. Me refiero en concreto al tema de la plenitud de control jurisdiccional de todas las actuaciones de los poderes públicos. Ciertamente se ha estudiado y aplicado el control de constitucionalidad de las normas, en principio con rango de ley, 
ahora incluso de las reglamentarias', pero se ha descuidado el de alguna otra potestad distinta de la estrictamente normadora cuya naturaleza y sobre todo cuyo control jurisdiccional es necesario clarificar cuanto antes. Es preciso que se acepte de una vez por todas que si una decisión cualquiera de un poder público no puede ser fiscalizada por ninguna vía de las previstas en nuestro Ordenamiento, los preceptos constitucionales y legales que disciplinan tales potestades serán meramente semánticos, nunca verdaderamente normativos. Parece haber acuerdo en que toda la Constitución es norma jurídica, pero si descubrimos algunas fallas en el sistema de control jurisdiccional previsto en nuestro Ordenamiento habrá que concluir que aún quedan zonas exentas de fiscalización jurisdiccional y por ello mandatos formalmente incluidos en la Constitución que tienen un alcance meramente ético o a lo sumo político. Ciertamente, el control político, que corresponde en España de forma eminente al Congreso de los Diputados y en última instancia al electorado, es importantísimo; pero insisto, si no existe control jurisdiccional posible, la norma en que se basa la decisión política no es vinculante, no pertenece al mundo del Derecho, no es verdadera norma jurídica ${ }^{2}$. Recordar este punto de partida resulta especialmente importante cuando la modificación de la normativa legal reguladora de la jurisdicción contencioso-administrativa se ha orientado teóricamente en este sentido y sin embargo ha supuesto, paradójicamente, un paso atrás significativo en la correcta resolución del problema.

Citaré algunos casos que pueden ilustrar la cuestión. Si el Congreso aprueba declarar el estado de sitio sin respetar la mayoria exigida o sin propuesta previa del Gobierno o lo hace para evitar que se celebren unas elecciones generales que presumiblemente harán cambiar la mayoría parlamentaria impidiendo así la renovación de las Cámaras ${ }^{3}$, habrá que aclarar qué recurso puede plantearse y ante

1 Véase la excelente obra de CAAMAÑo, F: El control de constitucionalidad de disposiciones reglamentarias, Madrid 1994 y la bibliografía citada al final de este libro. Durante varios años ni el Tribunal Supremo ni el Constitucional acertaron a solucionar el problema de la ausencia de una vía legal específica para controlar la constitucionalidad de los reglamentos.

2 En realidad, considerar que ciertas decisiones politicas jurídicamente formalizadas están sujetas únicamente a control político es negar en el fondo la distinción entre poder constituyente y poderes constituidos, puesto que se considera constitucionalmente legítima cualquier decisión del Gobierno siempre que cuente con el respaldo del Congreso y de éste siempre que el electorado no castigue a la mayoría que la adoptó.

${ }_{3}$ De acuerdo con el art. 116.5 CE no podrá procederse a la disolución del Congreso cuando estén declarados los estados de alarma, excepción o sitio. Cier- 
qué órgano jurisdiccional para que se pueda anular tal declaración por inconstitucional o ilegal, según los casos. Igualmente, si el Rey nombra Presidente del Gobierno a quien ho ha obtenido la mayoria precisa en el Congreso o sin que mediara convocatoria oficial de los diputados para la sesión de investidura ${ }^{4}$ o sin que se respetara cualquier otro aspecto procedimental de los previstos en la Constitución o en el Reglamento del Congreso, habrá que saber si cabe recurso de inconstitucionalidad o de amparo o al menos recurso contenciosoadministrativo contra dicho real decreto que aprueba un «acto políticon. Más aún, si a juicio de la mayoría del Congreso y del Senado el Rey se encuentra inhabilitado para ejercer su autoridad y entra el Príncipe heredero a ejercer la Regencia (art. 59.2 CE) ¿podrá evitarse que tal potestad sea utilizada abusivamente por la mayoría gobernante para desembarazarse de un Rey al que consideren más o menos hostil a su programa político ${ }^{5}$ Los ejemplos podrían multiplicarse, pero es mejor dejar para después el elenco de los supuestos que aqui van a analizarse.

Comenzaré por exponer el concepto de "acto constitucional" que aqui se propone, para distinguirlo de las normas de cualquier rango y de los actos administrativos o meramente políticos, y analizaré seguidamente cuáles son los actos jurídico-públicos que tienen la consideración de «actos constitucionales» y la dificultad de encontrar vías para su control jurisdiccional a la luz de las normas de procedimiento hoy existentes, incluida la nueva ley reguladora de la jurisdicción contencioso-administrativa recientemente aprobada.

tamente, debería entenderse que este precepto se refiere a la disolución anticipada del art. $115 \mathrm{CE}$, pero podría también interpretarse que se prorroga el mandato parlamentario (o que la Diputación Permanente asume los poderes de la Cámara) hasta que el retorno a la normalidad constitucional permita la celebración de las elecciones generales que quedarían así en suspenso mientras continúe la situación de anomalia.

4 El Tribunal Constitucional advirtió ya de la posibilidad de que una ley fuera declarada inconstitucional cuando no respete los preceptos del reglamento parlamentario, concretamente "cuando esa inobservancia altere de modo sustancial el proceso de formación de voluntad en el seno de la Cámara» STC 99/1987, FJ $1 .^{\circ}$. En el mismo sentido, la STC $36 / 1990$, FJ $2 .^{\circ}$. Es de suponer que tales vicios de procedimiento también invalidarían otras decisiones del Congreso distintas de la aprobación de leyes.

5 Recuérdese que el art. 81 de la Constitución de la Segunda República fue utilizado abusivamente en 1936 para destituir al Presidente Alcalá Zamora, bien que la posición constitucional de aquel Jefe de Estado republicano tuviera poco en común con la del actual Rey de España. 


\section{EL CONCEPTO DE "ACTO CONSTITUCIONAL»}

La complejidad de la idea que analizamos aconseja comenzar por acercarnos a ella de forma aproximada e incluso negativa frente a otras figuras afines y sólo después podremos definir positivamente el concepto.

\section{Aproximación a la idea}

Los diferentes órganos públicos tienen atribuidas por el Ordenamiento una serie de potestades que varían lógicamente de unos a otros. Igualmente disponen de unos instrumentos jurídicos para formalizar tales decisiones. Así, por ejemplo, las Cortes Generales y las Asambleas autonómicas aprueban con la forma de "ley" la mayor parte de las decisiones que constitucional o estatutariamente les corresponden. Del mismo modo, las potestades del Rey y del Gobierno se ejercen por medio del instrumento dispositivo que conocemos con el nombre de "real decreto". Por lo tanto, los términos "ley" y "real decreto", tal como aparecen configurados en nuestro Ordenamiento, hacen referencia a la forma que revisten las decisiones de tales órganos constitucionales, sin que a primera vista puedan diferenciarse las potestades que en cada caso se están ejerciendo por medio de tal instrumento. El concepto puramente formal de ley admitido en nuestra Constitución (vide infra) hace que la forma "ley» cubra completamente cualquier contenido posible. En todos los casos decimos que las Cortes han ejercido la potestad legislativa, tanto si dicha ley aprueba un nuevo Código penal como si decide la modificación de los límites provinciales (art. 141.1 CE), autoriza la celebración de un tratado internacional de cesión de parcelas de soberanía (art. 93) o acepta la abdicación del Rey (art. $57.5 \mathrm{CE})^{6}$. El régimen jurídico básico y por tanto el de impugnación y fiscalización de tales disposiciones es siempre el mismo cualquiera que sea su contenido?.

6 Por si fuera poco, el Tribunal Constitucional ha aceptado la legitimidad de las leyes singulares, esto es, de las que dictan normas para un solo caso. La doctrina sobre las leyes singulares en la STC 166/86, FF JJ 10 y 11.

7 Así, el ATC 46/1993, declaró la inadmisión de un recurso de amparo contra la Ley Canaria 2/1992, de expropiación de un edificio contiguo al palacio de las Cortes autonómicas por entender que denominándose «ley» no puede el Tribunal Constitucional entrar siquiera a valorar si su contenido es o no un acto administrativo concreto. Con tal de que se titule "ley" el contenido es indiferente a efectos de la via jurisdiccional utilizable para su impugnación. 
En cambio, con el real decreto no sucede lo mismo. Mediante él se pueden ejercer las potestades de normación, de dirección política o de dirección de la Administración civil o militar que la Constitución (art. 97) encomienda al Gobierno, y además las que -al menos formalmente-corresponden al Rey como Jefe del Estado. Ya en la Segunda República pudo decirse del decreto que «no es una categoría de contenido, sino una simple categoría formal, molde hueco en el que caben las expresiones materiales más varias" ${ }^{8}$. $Y$ algo parecido, aunque en menor medida, sucede con los "acuerdos" que pueden adoptar el Tribunal Constitucional ${ }^{9}$ o el Consejo General del Poder Judicial ${ }^{10}$ pues bajo esa forma pueden aprobarse cosas diversas, según la potestad que en cada caso se esté ejerciendo.

Por otro lado, si prescindimos de las formas y nos atenemos a la naturaleza real de los contenidos de tales disposiciones podemos hablar de diversas categorías relativamente bien delimitadas por los administrativistas. En efecto, podemos aceptar como punto de partida que todo acto jurídico-público o es una "norma» («disposición general» o "disposición» sin más) o es una «resolución» (un acto administrativo)"

En su acepción más común, se denomina "norma» a la disposición jurídica formulada de forma abstracta y general que se integra en el Ordenamiento jurídico modificándolo de algún modo y que se proyecta sobre un número indefinido de casos singulares a los que regu$\left.\right|^{12}$. Por el contrario la "resolución» o mejor el "acto administrativo» es

8 Cáceres Crosa, G.: El refrendo ministerial, Revista de Ciencias Jurídicas y Sociales, $n .^{\circ} 62$ y $66(1933-1934)$.

9 Así, junto a los acuerdos del Tribunal Constitucional que aprueban normas reglamentarias al amparo del art. 1.2 LOTC, están los que contienen actos administrativos singulares y concretos sujetos todos ellos a control jurisdiccional por la Sala 3. ${ }^{a}$ del Tribunal Supremo (art. 58.1 LOPJ y arts. 1.3.a. y 11.1.c. de la nueva LJCA).

10 Por medio de sus "acuerdos», lo mismo se puede aprobar un reglamento (art. 110 LOPJ), actos administrativos (Unos y otros fiscalizables ante la Sala 3. ${ }^{\text {a }}$ del Tribunal Supremo, art. 58.1 LOPJ y arts. 1.3.b. y 11.1.b. LJCA) o la propuesta al Rey para el nombramiento de dos magistrados del Tribunal Constitucional (nombramientos fiscalizables sólo por el Pleno del propio Tribunal Constitucional (art. 10.f. LOTC).

" Dejamos al margen una tercera categoría posible, la de los «contratos administrativos" que para nada afectan al tema que aquí se estudia.

12 Naturalmente el concepto de norma es mucho más complejo, pero partimos de la idea general más comunmente aceptada sin perjuicio de reconocer la existencia de objeciones $y$ excepciones que sin duda pueden hacerse y encontrarse 
concreto y singular, no altera en nada el Ordenamiento jurídico, sino que lo aplica a un caso concreto y se agota con su cumplimiento. Por otro lado, es sabido que todos los órganos constitucionales tienen potestades administrativas y por tanto no sólo el Gobierno y la Administración, sino el Congreso, el Senado, el Tribunal Constitucional y el Consejo General del Poder Judicial (a veces sus presidentes o sus órganos directivos colegiados) dictan verdaderos actos administrativos.

Desde el punto de vista del control jurisdiccional es importante recordar ya en este momento que los actos administrativos, cualquiera que sea el órgano del que procedan, son controlables siempre por los tribunales ordinarios, y si lesionan derechos fundamentales, también por el Tribunal Constitucional en vía de amparo. En cambio, el control de las normas se realiza según el rango: si tienen rango de ley por el Tribunal Constitucional, si tienen rango reglamentario por los tribunales ordinarios integrados en la jurisdicción contenciosa ${ }^{13}$.

Ahora bien, la diferencia acto-norma, que es válida en el nivel administrativo, resulta más borrosa si nos elevamos al nivel constitucional. En efecto. ¿Es una norma o es un acto el real decreto que declara el estado de excepción con la previa autorización del Congreso? ¿Y la disolución de las Cortes y convocatoria de elecciones generales? ¿Y el testamento del Rey o la prohibición del Rey al heredero de la Corona de que contraiga matrimonio con determinada persona? Además, existen ciertos actos indudablemente singulares pero difícilmente reconducibles a la categoria de "actos administrativos», como el nombramiento de magistrados del Tribunal Constitucional o de vocales del Consejo General del Poder Judicial o de la persona que ha de presidir alguno de estos órganos constitucionales, realizada por el Rey tras la pertinente propuesta.

a tal definición. Sobre la dificultad de encontrar un concepto de norma válido para todos los casos Cfr. BobBıo, N.: Teoría General del Derecho Versión española, Madrid 1991, págs. 113 y ss. y 141 y ss.; también Balaguer CaLlejón, F: Fuentes del Derecho I, Madrid 1991, pág. 113 y De Asıs Rolg, A.: La Ley como fuente del Derecho en la Constitución de 1978, en «Estudios sobre la Constitución española. Homenaje al profesor Eduardo García de Enterría» Tomo I, Madrid 1991, pág. 207. Esta dificultad se ha puesto también de manifiesto en la propia jurisprudencia constitucional, como puede comprobarse, por ejemplo, en la STC 27/1983, FJ 2.․

13 Me refiero, por supuesto al "control negativo", es decir, a la declaración de nulidad erga omnes de una disposición legal o reglamentaria, por tanto hacemos aquí abstracción del "juicio positivo" de constitucionalidad que deben hacer todos los jueces antes de aplicar la norma (sobreentendido en el art. $163 \mathrm{CE}$ ) y de los supuestos excepcionales en que los órganos del poder judicial pueden decidir sobre sí mismos sobre la validez constitucional de una norma con rango de ley (leyes preconstitucionales, ultra vires del decreto legislativo). 
Este tipo de actos jurídico-públicos que no pueden ser reducidos a la idea de norma o de acto administrativo no se producen sólo en el complejo orgánico formado por el Rey y el Gobierno, sino también en el poder legislativo, en las Cortes Generales, pues ¿qué naturaleza tiene la inhabilitación regia? ¿Y la designación del Presidente o de los miembros de la Mesa de la Cámara o del Defensor del Pueblo? ¿Y la declaración del estado de sitio por el Congreso? ¿Y la autorización del Senado al Gobierno para que utilice la potestad de compulsión sobre las Comunidades autónomas del art. $155 \mathrm{CE}$ ?

Analicemos un poco la cuestión e interroguémonos por qué tales decisiones formalizadas jurídicamente no encajan en la idea de norma ni en la de acto administrativo.

Partiendo de la distinción administrativista entre acto y norma podemos afirmar que todo acto juridico-publico singular consiste en la aplicación de una norma general y abstracta a un caso concreto y determinado. Así, cuando la norma que regula el ascenso de ciertos funcionarios es aplicada e individualizada al ascender el Gobierno o los órganos administrativos superiores a un determinado funcionario, decimos hallarnos ante un acto administrativo singular y concreto que no innova ni modifica para nada el Ordenamiento y que se agota con su cumplimiento. Sin embargo, en los casos más arriba mencionados la norma que se aplica a un supuesto concreto (por ejemplo la inhabilitación del Rey) es la propia Constitución. Y ello sin perjuicio de que en ocasiones la normación constitucional haya sido completada por una norma de rango legal (caso de la declaración de los estados de anomalía, que no sólo debe respetar los límites y procedimientos de los arts. 55 y $116 \mathrm{CE}$, sino todas las previsiones de la LO 4/1981, de 1 de junio y los arts. 162 a 165 del Reglamento del Congreso). Se trata pues de actos singulares y concretos que se incardinan directamente en la Constitución.

Pero no podemos conformarnos con un criterio tan formalista. Si tales actos están directamente normados por la Constitución es porque su importancia, es decir, su naturaleza intrínseca, es constitucional. O como ha dicho en alguna ocasión nuestro Tribunal de Garantías porque versan sobre "materia constitucional» ${ }^{14}$. Más adelante analizaremos esta cuestión.

En cualquier caso, sea cual fuere la naturaleza exacta de tales decisiones políticas aprobadas con el mismo instrumento formal con que se aprueban normas y actos administrativos, lo cierto es que constitu- 
yen un tertium genus realmente distinto de los otros dos. Denominaremos aquí "actos constitucionales» a todos aquellos actos jurídico-públicos que ni son normas ni son actos administrativos:

a) No son normas propiamente dichas, quiere decir que no establecen un mandato general y abstracto que modifique el Ordenamiento y se incorpore a él, sino que realizan una ordenación concreta $y$ singular, sea por referirse a personas determinadas, sea por hacerlo a momentos, situaciones o hechos concretos.

b) No son actos administrativos porque no están sujetos al Derecho administrativo sino sólo al Derecho constitucional ${ }^{15}$, cuestión esta que más adelante se analizará.

Así pues, denominaremos actos constitucionales, provisionalmente y hasta precisar mejor su concepto, a todos los actos jurídico-públicos que realizan una ordenación concreta y singular sin que puedan ser objeto de control contencioso-administrativo por no corresponder su naturaleza a la idea comúnmente aceptada de actos administrativos.

Ahora bien, ¿Qué órgano pueden dictar un acto constitucional? En principio, sólo las Cortes Generales (o una de las Cámaras) y el Rey. En el primer supuesto unas veces se hará con forma de "ley", en cuyo caso se considera siempre como norma a efectos de su control jurisdiccional, pero otras veces no (llámese "acuerdo" o "resolución" parlamentaria). En el segundo caso, es decir, cuando el acto constitucional es un acto regio, se entiende que la forma será siempre la de real decreto. Más adelante tendremos que añadir también como posibles sujetos a las Asambleas autonómicas y a los Presidentes de las Comunidades Autónomas en cuanto ejercen funciones análogas a las que realizan las Cortes Generales y el Rey al dictar determinados actos constitucionales.

\section{Definición de acto constitucional}

¿Cuál es entonces la verdadera naturaleza de los actos constitucionales? ¿Es posible dar una noción positiva del concepto? Si obser-

15 La afirmación no es mía: «Este es el caso ...de los actos constitucionales en que se plasman las relaciones entre los Altos Organos del Estado...»; «...su actividad no es administrativa, sino política, y está sometida, por tanto al Derecho constitucional" Garcia de Enterria, E. y Fernández, T.R.: Curso de Derecho Administrativo I. 5. Edición, Madrid 1989, pág. 31. Lo interesante de esta afirmación es que procede de quienes con más rotundidad han defendido la desaparición, tras la aprobación de la Constitución de 1978 , de los «actos políticos» del Gobierno, como veremos más adelante. 
vamos todos los supuestos mencionados hasta ahora comprobamos que, además de no ser propiamente hablando normas ni actos administrativos, todos ellos se refieren a una de estas tres materias:

1.') La determinación de las personas que han de ocupar los puestos de gobernantes superiores del Estado.

$2 .^{\circ}$ La modificación de preceptos y garantías constitucionales durante un tiempo concreto y determinado: estados de anomalía, por una parte, que alteran el régimen ordinario del ejercicio de los derechos, deberes y libertades del ciudadano (arts. 55.1 y $116 \mathrm{CE}$ ) ${ }^{16}$ e intervención excepcional del Estado en las Comunidades Autónomas pudiendo suspender durante cierto tiempo preceptos constitucionales y estatutarios sobre distribución territorial del poder (art. $155 \mathrm{CE}$ ).

$\left.3 .{ }^{\circ}\right)$ Autorizaciones, convalidaciones o ratificaciones de normas jurídicas con rango de ley (y aun de rango constitucional) que son necesarias para la validez de tales normas (por las Cortes de ciertos tratados, art. $94 \mathrm{CE}$, por el Congreso de los decretos leyes, art. $86 \mathrm{CE}$, por el electorado de las reformas constitucionales, arts. 167.3 y 168.3$)^{17}$.

Se trata pues en todos los casos de actos jurídicos de eficacia en cierto modo constitucional o al menos legislativa. La norma constitucional que otorga competencias o atribuye funciones no puede ser eficaz hasta que un individuo (o varios en el caso de los órganos constitucionales colegiados) con nombres y apellidos ocupan el cargo. De igual modo, carecen temporalmente de eficacia plena los preceptos constitucionales que determinan el estatuto básico de las libertades del ciudadano y los que regulan el régimen básico de la distribución territorial del poder cuando, en uso de potestades excepciones constitucionalmente reconocidas, dichos preceptos quedan temporalmente en suspenso. Igualmente, dado el rango jerárquico de los decretos-leyes y

16 La declaración del estado de guerra (art. 63.3 CE), pese a lo desdibujado de esta figura en nuestro Ordenamiento, no cabe duda de que sería, si es que llegase a producirse, lo cual es más que dudoso, un acto constitucional. Por lo pronto haria legítima la aplicación de la pena de muerte (art. $15 \mathrm{CE}$ ) pero no con la actual legislación penal militar $y$ además impediria iniciar una reforma de la Constitución (art. $169 \mathrm{CE}$ ).

17 Con respecto al real decreto de convocatoria de referendum, téngase presente que la decisión que tome el pueblo, supuesto que sea respetada (referendum "consultivo" art. 92.1 CE), puede considerarse también un acto constitucional, puesto que la consulta popular habrá de versar sobre «decisiones políticas de especial trascendencia». Por no mencionar otros tipos de referenda previstos en la Constitución con evidente eficacia legislativa (art. 151.2.3. ${ }^{\circ} \mathrm{CE}$, ratificación de los Estatutos de autonomía) o incluso constituyente (arts. 167.3 y $168.3 \mathrm{CE}$ ). 
de los tratados internacionales en nuestro sistema de fuentes, la convalidación de los primeros y la autorización para la ratificación de los segundos tiene eficacia legislativa innegable.

Por otro lado es claro que todos los supuestos mencionados se encuentran directamente subordinados a la Constitución, es decir, aplican a un supuesto concreto una norma que forma parte de la Constitución formal.

En conclusión, podemos definir los actos constitucionales como aquellos actos jurídico-públicos singulares y concretos directamente incardinados en la Constitución y de eficacia en cierto modo constitucional o al menos legislativa, bien porque constituyen un complemento imprescindible para la plena efectividad de los preceptos constitucionales, bien porque son necesarios para la validez de normas jurídicas con rango de ley. Téngase en cuenta que los actos constitucionales que sirven para enervar diversos preceptos constitucionales (garantías de los determinados derechos, autonomía de las Comunidades autónomas) en realidad son también complemento necesario para la plena efectividad de otro precepto constitucional: el que prevé la suspensión de los otros en casos especiales (arts. 116 y 155 respectivamente).

Según esto, serán actos constitucionales todos los que determinen la designación de las personas concretas que han de integrar los órganos superiores de gobierno y en cambio serán actos administrativos los de designación de las personas que integren cualquier órgano público de inferior categoría ${ }^{18}$. Igualmente, diremos que son actos constitucionales los previstos en los arts. 116 y $155 \mathrm{CE}$, y en cambio será acto administrativo el real decreto de convocatoria de elecciones municipales (art. 185 LOREG). Por eso también, junto a los actos cons-

18 Por ello, en cierto modo deberán ser considerados actos constitucionales las credenciales de diputados y senadores expedidas por la Administración electoral correspondiente y las actas de escrutinio elaboradas por las correspondientes Juntas Electorales. De hecho, en numerosos paises se encarga al Tribunal Constitucional la revisión jurisdiccional de dichas actas, sea en única instancia, sea como última tras su impugnación ante los órganos judiciales. Se trataría propiamente de un acto constitucional emanado del electorado. De la experiencia histórica y comparada (véase PARdo Falcón, J.:Algunas consideraciones sobre el control de las actas electorales en el Derecho comparado $y$ en la Historia constitucional española, «REP», n. ${ }^{\circ} 99,1998$, págs. 175 a 188) se extrae la conclusión de que las actas han sido y son objeto de control por el propio Parlamento o por los órganos jurisdiccionales, sobre todo en tiempos recientes, por el Tribunal Constitucional (véase la nota $n .^{\circ} 93$ ). En este sentido resulta muy significativo que sea función frecuente de los tribunales constitucionales, entre ellos el nuestro, el control sobre los actos de designación de sus propios miembros (art. 2.1.g. LOTC). 
titucionales regios y parlamentarios, podemos hablar de otros autonómicos: la disolución de la Asamblea por su Presidente ${ }^{19}$, mientras que los actos parlamentarios que determinan la persona del Presidente autonómico (investidura, censura) se integran en realidad en un acto regio complejo, el real decreto de nombramiento de Presidente de la Comunidad Autónoma.

Sin embargo es preciso matizar algo más las anteriores afirmaciones. Algunos actos constitucionales tienen una cierta dimensión normativa. Así, el real decreto de disolución de las Cortes contiene normas sobre la convocatoria de elecciones que se realiza a la vez. Y está legalmente previsto (arts $6.2,11,13,14,15,32.2$ y 35 de la Ley Orgánica reguladora de los estados de alarma, excepción y sitiol que la declaración de los estados de anomalía -y las correspondientes autorizaciones parlamentarias cuando procedan-contengan también normas, es decir, mandatos generales y abstractos que se proyectan sobre un número indeterminado de casos singulares, al menos durante el tiempo en que esté en vigor dicho estado de anomalía. Es de suponer que algo similar sucedería con la autorización del Senado y el real decreto de intervención excepcional del Estado en las Comunidades autónomas del art. $155 \mathrm{CE}$. Lo que sucede en estos casos es que el acto constitucional en cuestión tiene una naturaleza mixta acto-norma. Algo parecido a lo que ocurre en Derecho administrativo con la convocatoria de unas oposiciones: es acto singular y concreto pero contiene unormas» que se proyectan sobre un número indeterminado de personas $y$ supuestos concretos. Es por esto que en algunas ocasiones el Tribunal Supremo ha creido que el real decreto de convocatoria de elecciones generales era un reglamento y como tal to ha enjuiciado, como veremos más adelante.

Pues bien, del mismo modo que la convocatoria de una oposición participa más de la naturaleza del acto administrativo que de la de norma reglamentaria, lo mismo la disolución de las Cortes y convocatoria de elecciones es más un acto singular que determina (en su fase final para unos o como elemento necesario previo para otros) las personas que ocuparán el poder legislativo, que una norma electoral propiamente dicha. Y lo mismo sucede con la declaración de los estados de anomalía: la validez de tales «normas» se circunscribe al tiem-

19 Tanto si el Presidente autonómico utiliza el derecho de disolución anticipada (posibilidad que hoy sólo tienen País Vasco, Cataluña, Galicia, Andalucía y desde hace poco Aragón), como si la disolución está ordenada para fecha concreta en la Ley electoral (art. 42.3 LOREG) y en los respectivos estatutos de autonomia. 
po y ocasión concreta y precisa de ese estado declarado y no se incorpora por tanto al Ordenamiento objetivo ni lo modifica propiamente hablando.

Este tipo de actos constitucionales tienen pues dos contenidos distintos: primero, un mandato concreto y determinado (se disuelven las Cortes, se declara el estado de excepción, se interviene en la Comunidad Autónoma que actúa contra los intereses generales de España); en segundo lugar y como consecuencia de lo anterior, en uso de la habilitación constitucional para cuando sea tomada una decisión de esta naturaleza, se dictan las condiciones concretas en que, dentro de las previsiones constitucionales y legales previas, se pondrá en práctica la decisión tomada.

Por lo demás, todos los actos constitucionales, aun los más estrictamente singulares, tienen una dimensión normativa evidente. Supongamos que las Cortes Generales inhabilitan al Rey (mejor, reconocen la situación de inhabilitación regia, art. 59.2 CE) y que ante los tribunales fuera impugnado un real decreto firmado por dicho Monarca que lleva fecha posterior a la decisión parlamentaria ¿acaso no sería declarado nulo dicho real decreto por haber sido expedido por quien ya no ostentaba la condición de Jefe del Estado? ¿Y qué norma estaría aplicándose al dictar tal sentencia sino la resolución parlamentaria que inhabilita (o reconoce la inhabilitación) del Rey? Ciertos actos constitucionales, aunque no sean normas en sentido estricto, en cuanto constituyen el complemento necesario a un precepto constitucional sin el cual dicho precepto no puede actuarse, ocupan el lugar de una verdadera norma a la hora de enjuiciar la validez de cualquier acto jurídico-público que se dicte apoyándose en aquél. Esta afirmación es de la máxima importancia para la determinación de las posibles vías de control jurisdiccional de los actos constitucionales que en la segunda parte de este trabajo se estudia.

\section{Actos constitucionales y actos políticos}

Según lo expuesto hasta ahora, podría parecer que la categoría de actos jurídico-públicos que aquí denominamos actos constitucionales correspondiera con lo que la doctrina y la LJCA de 1956 denominan "actos políticos" o "actos de gobierno" (o del Gobierno) que ha hecho desaparecer la nueva Ley Jurisdiccional.

Sin embargo, los actos constitucionales no son los actos políticos. Pese a lo que advertía la Exposición de motivos de la LJCA de 
1956, los actos políticos sí son (al menos hoy lo son, como lo fueron también antes de esa Ley $^{20}$ ) una especie dentro de los actos administrativos discrecionales: aquellos de contenido y naturaleza eminentemente política, y por tanto con un fuerte componente de oportunidad. Si el Gobierno se niega a autorizar una consulta popular a nivel municipal rechazando la solicitud de la Corporación, no podemos hablar de acto constitucional, sino de acto político. En este y otros casos semejantes existe un elemento de discrecionalidad y de oportunidad política que nunca podrá ser objeto de control jurisdiccional. Por eso, la nueva Ley de la Jurisdicción Contencioso-administrativa, por más que rechace formalmente la permanencia de tales actos políticos del Gobierno no susceptibles de control jurisdiccional, se tiene que conformar con permitir el control de los elementos reglados del mismo, nunca de los aspectos de mera oportunidad política que siempre serán discrecionales (art. 2.a). Los Ilamados actos políticos del Gobierno serán pues actos de contenido político evidente pero tan sujetos al Ordenamiento jurídico como los demás, y por ello anulables por los tribunales contencioso-administrativos si se dictan sin respetar todos los preceptos constitucionales, legales o reglamentarios que los regulan.

Pero los actos constitucionales no son actos administrativos de contenido político, no son actos administrativos discrecionales, porque no son actos administrativos en absoluto. $Y$ no sólo porque no son actos del Gobierno, sino de las Cámaras o del Rey, sino porque afectan vitalmente al proceso político, y por eso se encuentran directamente subordinados a la Constitución, al contrario de los actos politicos simples. Es evidente que los actos constitucionales tienen también un contenido político y de oportunidad innegable, más aún, se trataría de los actos políticos supremos en la vida del Estado. Por ello, llamaremos aqui actos políticos simples o actos meramente políticos a los actos jurídico-públicos que teniendo una naturaleza y contenido más o menos político no alcanzan sin embargo la categoría de actos constitucionales.

Por otra parte, junto a los actos meramente políticos del Gobierno existen también los actos políticos de las Cámaras, o mejor, de sus órga-

20 En su origen los actos políticos del Gobierno eran una modalidad de actos discrecionales, como se demuestra claramente en el art. $4 .^{\circ}$ del Reglamento de 29 de diciembre de 1890 al desarrollar el art. 4.1 de la Ley de 13 de septiembre de 1888 de lo contencioso-administrativo. Cfr. EmBid IRUjo, A.: La justiciabilidad de los actos de gobierno, en "Estudios sobre la Constitución española. Homenaje al profesor Eduardo Garcia de Enterría», Tomo III, Madrid 1991, pág. 2.700. 
nos de dirección ${ }^{21}$. Sin perjuicio de lo que más adelante diremos, debe tenerse en cuenta que cuando las Cámaras parlamentarias actúan como tales (es decir, sus Plenos y en algunos casos de delegación las Comisiones) no dictan ni pueden dictar actos administrativos ni tampoco actos meramente políticos: toda decisión singular de una Cámara parlamentaria, sea nacional sea autonómica, que tenga eficacia jurídica externa directa es un acto constituciona ${ }^{22}$. $O$ dicho en otros términos: las Cámaras parlamentarias o dictan normas ${ }^{23}$ o dictan actos constitucionales ${ }^{24}$. La categoria de actos meramente políticos queda reservada, en sede parlamentaria, a ciertas decisiones singulares y concretas que toman los órganos rectores de las Cámaras. Para este tipo de actos jurídico-públicos reservaremos aquí el nombre de actos parlamentarios simples, como equivalente al de actos meramente políticos del Gobierno. Se trataría de la única especie de actos políticos que con la nueva LJCA van a quedar excluidos del control judicial, a tenor de lo dispuesto en los arts.1.3.a y 12.1.c que no contemplan la existencia de actos políticos de las Cámaras.

Ahora bien, ¿cuál es la frontera entre los actos constitucionales $y$ los actos meramente políticos? ¿Conforme a qué criterio podemos distinguir éstos de aquéllos? A mi modo de ver dos diferencias, una formal y otra material distinguen ambos tipos de actos:

21 Cfr. Embid Inujo, A.: Actos políticos del Gobierno y actos políticos de las Cámaras parlamentarias. Reflexiones en torno a su control por la jurisdicción contencioso-administrativa, "RCG», n..$^{\circ} 13$ (1988), págs. 53 y ss.

22 Ello se debe a que, sin perjuicio de lo que luego se dirá sobre el parámetro de enjuiciamiento de la constitucionalidad de los actos constitucionales, las decisiones parlamentarias no se subordinan entre sí, sino sólo a la Constitución -al Estatuto, en el caso de las Cámaras autonómicas-. En el fondo subyace el problema de si las Cortes están sujetas sólo a la Constitución o también al resto del Ordenamiento jurídico. Considero que la solución alemana (art. 20.3 LFB) es la auténtica y la única posible también aquí, pese a que fue rechazada la enmienda que proponía la clarificación de esta cuestión en el actual art. 9.1 CE. Cfr. GarRido Falla, F: Co-

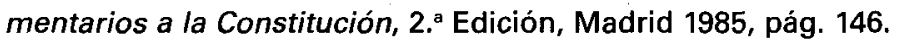

${ }^{23}$ Téngase presente que toda norma dictada por una Asamblea parlamentaria tiene rango de ley, salvo los extraños reglamentos administrativos emanados por las Asambleas de algunas Comunidades Autónomas uniprovinciales. De forma que hasta hace poco incluso las normas dictadas por los órganos de dirección de las Cámaras para aclarar o llenar lagunas del Reglamento parlamentario tenían la consideración de normas con rango de ley (ATC 183/1984, ATC 244/1986, STC 118/1988, STC 15/1992, etc). Sin embargo, tras la STC 44/1995, ha de entenderse que ninguna resolución de los órganos de dirección de las Cámaras (sea norma, sea acto) tienen fuerza de ley.

${ }_{24}$ Salvo, quizás, en el supuesto en que la Asamblea actúa como órgano cuasi-judicial, es decir, cuando concede o deniega un suplicatorio para procesar a un miembro de la Cámara o en el supuesto del art. 102.2 CE. 
a) Desde un punto de vista estrictamente formal, los actos constitucionales están normados directamente por la Constitución, incluso cuando existen normas legales que sirven como parámetro de enjuiciamiento de la constitucionalidad de tales actos. En cambio, los actos meramente políticos se incardinan siempre en una ley. Si decíamos que todo acto jurídico-público singular es la aplicación de una norma general a un supuesto concreto $y$ determinado, y que un acto constitucional es aquél en que la norma que se aplica es la propia Constitución, entonces un acto político es, al igual que un acto administrativo cualquiera, la aplicación de una norma legal (o reglamentaria) a un supuesto concreto de la vida.

b) Desde un punto de vista sustancial la diferencia es que el acto constitucional tiene eficacia legislativa o incluso constitucional complementaria, mientras que el acto politico tiene eficacia puramente ejecutiva. ¿Cómo saber si un acto tiene eficacia legislativa o constitucional?, pues cuando tiene la virtualidad de enervar preceptos legales o constitucionales, sea directamente, sea como mera posibilidad. Es pues un acto constitucional el que determina las personas que van a componer los órganos constitucionales: los Parlamentos porque hacen $y$ derogan leyes, los Gobiernos porque pueden dictar normas con rango de ley, el Tribunal Constitucional porque es el "legislador negativon, el Consejo General del Poder Judicial porque puede interponer conflictos de atribuciones que lleven a la anulación de normas legales y porque decide sobre la composición del "legislador negativo" y el Defensor del Pueblo porque puede interponer recursos de inconstitucionalidad que provoquen la nulidad de normas legales. En el ámbito autonómico son actos constitucionales los que determinan las personas que han de integrar el Gobierno -legitimado para presentar recursos de inconstitucionalidad, art. 162.1.a CE- y el Parlamento -que además aprueba verdaderas leyes- En cambio, ni el Ministerio Fiscal, ni el Consejo de Estado, ni el Consejo Económico y Social, ni el Tribunal de Cuentas cuentan entre sus potestades la de anular normas legales ni la de contribuir de forma necesaria a su anulación.

Por eso la Constitución ha recogido el procedimiento para la designación de los miembros (y por supuesto presidentes y otros órganos directivos) de todos los órganos que tienen participación en la creación de normas legales o que pueden producir su nulidad o al menos instarla. Pero también aquí sucede que en ocasiones no se da una coincidencia perfecta entre la materia y la forma constitucional a la hora de regular el procedimiento de designación de los componentes o de los cargos directivos de los órganos mencionados. Tal es el caso 
del Fiscal General del Estado y, en sentido contrario del Vicepresidente del Tribunal Constitucional y del mismo cargo del Consejo General del Poder Judicial. En el primer supuesto, conforme al criterio formal nos encontraríamos ante un acto constitucional, pues la norma que se aplica al nombrarlo es el art. $124.4^{*} \mathrm{CE}$, si bien el Estatuto orgánico del Ministerio Fiscal da normas más detalladas al respecto. $Y$ sin embargo, según el criterio sustancial el nombramiento de Fiscal General del Estado es un acto político y no un acto constitucional. En el segundo caso, los respectivos Vicepresidentes no son mencionados siquiera en la Constitución, sino en la LOTC y en la LOPJ respectivamente, pero el lugar funcional que ocupan tales cargos nos lleva a considerar tales nombramientos como actos constitucionales. 0 dicho en otros términos: aunque casi siempre el criterio formal para distinguir los actos políticos de los actos constitucionales es acertado, en algunos casos límite hay que recurrir al criterio material para asegurarnos que nos encontramos ante un acto constitucional y no ante un acto meramente político.

\section{CLASIFICACIÓN DE LOS ACTOS CONSTITUCIONALES}

Como se habrá podido comprobar, la variedad de actos que encajan dentro del concepto de acto constitucional que aqui se defiende es tan amplia que urge clasificar los diversos tipos que pueden presentarse en la práctica o que están previstos en nuestro Ordenamiento. Sin embargo, existen una gran variedad de criterios conforme a los cuales los actos constitucionales pueden clasificarse. En este sentido, pueden hacerse al menos cinco clasificaciones: según el autor, según el contenido real, según su eficacia jurídica, según la forma que revisten y según su naturaleza. En la primera de ellas se intentará exponer de forma exhaustiva el catálogo completo de los actos constitucionales, pero en el entendido de que existen casos dudosos que se encuentran en la frontera misma con los actos políticos simples, y por tanto puede suceder que además de los aquí mencionados exista algún otro acto constitucional.

\section{Según su autor}

En principio existen sólo dos órganos capaces de dictar actos constitucionales: el Rey y las Cortes Generales lo alguna de las Cámaras). Pero por traslación, pueden hacerlo también los Presidentes de las 
Comunidades Autónomas y las Asambleas legislativas de las mismas. En cierto sentido, también el pueblo como electorado puede ser autor de algunos actos constitucionales. Dejaremos por el momento estos últimos para centrarnos en los dos primeros, pues en ellos se agrupa la casi totalidad de los actos constitucionales.

Esta distinción entre actos regios y actos parlamentarios nos dará también una pista histórica para rastrear el por qué de tales actos, en cierto modo soberanos, desde la época en que se consideró que la soberanía era compartida entre Rey y Cortes. El hecho mismo de que constituyan el último reducto de actos del poder no fiscalizables, incluso cuando se ha normalizado el control de constitucionalidad de las leyes, nos indica que en ellos se ejerce un poder que fue soberano hasta relativamente poco tiempo y por eso parece que incluso hoy el Ordenamiento quisiera seguir considerándolos como actos de soberanía.

1. ${ }^{\circ}$ Actos constitucionales regios. Para poner un poco de orden en la gran variedad y diversidad de actos constitucionales que son considerados como actos del Rey es preciso hacer primero unas aclaraciones en torno al instrumento dispositivo denominado "real decreto" 25 . Podemos definirlo como la disposición jurídica firmada por el Jefe del Estado, que habla en primera persona ("Dispongo»), que sirve para formalizar las decisiones que el Ordenamiento atribuye al Gobierno, a su Presidente o al propio Rey.

Como puede apreciarse, se trata de un concepto puramente formal, pues, por su propia naturaleza, no cabe otro tipo de definición del real decreto. Ello se debe a que su contenido es variadísimo, de ahí que lo sean también su tipología y regímenes juridicos. Los diferentes tipos de reales decretos sólo tienen en común los aspectos formales, es decir, la firma regia al pie del documento, el refrendo por parte de un miembro del Gobierno (art. 56.3 CE salvo en los escasísimos supuestos en que no precisa refrendo, art. $65.2 \mathrm{CE}$, o éste corresponde al Presidente del Congreso, art. 64.1 CE) y la redacción en primera persona como si se tratara de una decisión emanada de la voluntad del Monarca.

De acuerdo con la definición propuesta se podría entonces hablar de dos tipos de reales decretos: los del Rey y los del Gobierno,

25 Resulta sorprendente el poco interés con que la doctrina ha tratado el real decreto como instrumento dispositivo. Afortunadamente ya existe una monografía sobre el tema que estimo muy clarificadora para comprender la diversidad y heterogeneidad de contenidos que ha tenido y tiene en nuestro Derecho el real decreto: DE LA Iglesia, A.: El Gobierno por decreto. Pamplona, 1997. Especialmente el capítulo cuarto sobre el panorama actual de este instrumento dispositivo. 
según cuál sea el órgano constitucional que ejerce en cada caso sus potestades. Sin embargo, las funciones regias son, en realidad, puramente formales, de modo que son ordinariamente ejercidas por otros órganos constitucionales, entre ellos el propio Gobierno. En otras palabras, prácticamente no existen decretos estrictamente del Rey, porque salvo la excepción del art. 65.2 (nombramiento y sustitución de los miembros civiles y militares de la Casa del Rey), en todos los demás casos, el Rey se limita a prestar su firma al pie de un documento cuyo contenido ha sido decidido por otros órganos constitucionales ${ }^{26}$. Hay por tanto tres supuestos constitucionalmente previstos:

a) Aquellos casos en los que el Rey decide libremente el contenido del real decreto. El único supuesto expresamente previsto es el del art. 65.2 CE.

b) Aquellos casos en los que el Rey se limita a formalizar una decisión tomada por el Gobierno en el ejercicio de sus potestades ordinarias, las mencionadas en el art. $97 \mathrm{CE}$. Aquí se incluyen la inmensa mayoría de los reales decretos. Su justificación es meramente histórica: el Monarca ha sido tradicionalmente la cabeza del poder ejecutivo, por lo que, todavia hoy, se ha querido mantener la ficción de que toda decisión tomada por el Gobierno se dicte amparándose en la autoridad regia. Según esto, la Constitución ha establecido que "corresponde al Rey: ...f) expedir los decretos acordados en Consejo de Ministros" (art. 62); a pesar de que en ellos se exprese la voluntad colectiva del Gobierno y no la del Rey. Por esta razón la Constitución exige que el refrendo de los decretos corresponda a los miembros del Gobierno, salvo dos supuestos especiales (art. 64.1).

c) Aquellos casos en que el Rey formaliza una decisión tomada por otro órgano constitucional referida normalmente a las personas que han de integrar o en su caso presidir alguno de tales órganos. En efecto, la Constitución ha establecido que el nombramiento de las per-

${ }^{26}$ No se trata pues de entrar en la cuestión, propuesta por M. HERRERO DE Mıñón de si "es preciso que el Rey no sea mero titular, sino que ejerza, como la Constitución exige, aquellas competencias que la Constitución y las leyes le atribuyen». Comentario al artículo 56: El Rey, en ALZAGA VILLAAMIL, O. (dir.);:Comentarios a la Constitución española de 1978». Tomo V. Madrid 1997, pág. 55. Esta cuestión es irrelevante para el tema que aquí tratamos: los actos regios (los "decretos del Rey») deben diferenciarse de los actos del Gobierno o de su Presidente no porque el Monarca tenga una mayor o menor posibilidad de intervenir en la decisión que en cada caso se formaliza, sino porque los decretos del Rey contienen actos constitucionales y los del Gobierno contienen normas, actos administrativos, o actos meramente políticos. 
sonas que ocuparán tales cargos se hará por el Rey a propuesta de otro órgano constitucional. El Rey se limita pues a nombrar a aquél que le propone, con propuesta vinculante, uno de los poderes del Estado. Estos decretos se justifican por el deseo de dar una mayor solemnidad al nombramiento de los altos cargos del Estado ${ }^{27}$. Pero, en cualquier caso, es importante resaltar que tales reales decretos son verdaderos actos del Rey, no propiamente del órgano que los propone, como expresamente ha recordado el Tribunal Constitucional ${ }^{28}$.

Por tanto, cuando en la definición de real decreto se habla de funciones del Rey ha de entenderse que son funciones atribuidas a otros órganos y que sólo formalmente son regias, salvo, claro está, el nombramiento o cese de los miembros de su Casa (art. 65.2 CE).

Al ser el real decreto una pura forma jurídica susceptible de contenidos muy diversos es preciso siempre determinar la naturaleza de una disposición de este tipo, pues lo mismo puede contener normas que actos, y las normas pueden ser con rango de ley (decreto-ley ${ }^{29}$, decreto legislativo) o de inferior rango (decreto reglamentario) y los actos

27 En casi todas las Monarquías actuales corresponde al Rey el nombramiento de las personas que han de presidir todos los órganos políticos relevantes, a excepción de los que tienen origen democrático directo. En España, al Presidente del Gobierno (art. 62.d. CE), al Presidente del Consejo General del Poder Judicial (art. 123.2 CE) al del Tribunal Constitucional (art. $160 \mathrm{CE}$ ), incluso a los Presidentes de todas las Comunidades Autónomas (art 152.1 CE y concordantes de los diversos Estatutos de autonomia). Más aún, todos los miembros de algunos de estos órganos son nombrados por el Rey, como es el caso del Gobierno (art. 62.e. CE) del Tribunal Constitucional (art $159 \mathrm{CE}$ ) y del Consejo General del Poder Judicial (art 122.3 CE). La designación de otros órganos de relevancia constitucional o de sus presidentes sería un caso limite entre acto constitucional y acto administrativo, así, la designación de los Presidentes del Consejo de Estado (arts. 6 y 7 Ley 3/1980, del Consejo de Estado) del Tribunal de Cuentas (art. 29 de I LO 2/1982, de 12 de mayo, del Tribunal de Cuentas) o de todos los magistrados del Tribunal Supremo y de otros cargos judiciales superiores (art. 139 LOPJ). En la misma situación límite se encuentra la designación por el Rey del Fiscal General del Estado (art. 124.4 CE).

${ }^{28}$ "El Rey lleva a cabo actos derivados de una propuesta, o una actividad anterior, de órganos muy diversos, como pueden ser el Congreso, el Senado, el Gobierno, el Consejo General del Poder Judicial o los órganos de las Comunidades Autónomas" (STC 8/1987, FJ 3.\%). En rigor por tanto la propuesta es del órgano a quien corresponda, pero el real decreto es un acto del Rey. Así lo dijo la propia Sentencia citada al referirse al acto constitucional objeto de impugnación: «el nombramiento de Lehendakari es un acto del Rey" (FJ 2.\%).

${ }_{29}$ Con el decreto-ley sucede igual que con la ley: el nombre determina el régimen jurídico de la disposición con independencia de la naturaleza real del contenido; por eso es posible y aun frecuente que un decreto-ley contenga un acto en vez de una norma. 
pueden ser constitucionales o meros actos administrativos. Nos centraremos en los actos constitucionales, que es el objeto del presente estudio, sin perjuicio de las aclaraciones que aparecerán después. Los denominaremos pues, "reales decretos constitucionales» ${ }^{30}$.

Según el órgano constitucional del que procede la decisión formalizada en el real decreto constitucional, podemos distinguir entre los que dicta el Rey a propuesta del Congreso, del Senado, del Gobierno o de su Presidente, del Tribunal Constitucional, del Consejo General del Poder Judicial o de las Asambleas parlamentarias de las Comunidades autónomas. Son los siguientes:

a) Del Congreso de los Diputados: son aquellos reales decretos que suponen la formalización jurídica de ciertas decisiones políticas adoptadas por esta Cámara en el ejercicio de competencias constitucionales. Dentro de este grupo podemos citar cuatro supuestos: $1 .^{\circ} \%$. Real decreto de nombramiento del Presidente del Gobierno (art. 62. d. $\mathrm{CE}$ ), cualquiera que haya sido la vía por la que el Congreso le haya otorgado su confianza (investidura del art. 99, censura del art. 113). Por expreso mandato constitucional (art. 64.1) este real decreto es siempre refrendado por el Presidente del Congreso de los Diputados. 2.\%. Real decreto de disolución automática de las Cortes. Aparte el supuesto de reforma constitucional del art. $168 \mathrm{CE}^{31}$, también pueden ser disueltas las Cámaras -las dos- por decisión del Congreso: cuando no consigue ponerse de acuerdo en investir a ningún candidato a la Presidencia del Gobierno pasados dos meses de la primera votación (art. 99.5 CE). EI refrendo corresponde al Presidente del Congreso (art. 64.1 CE). $3^{\circ}{ }^{\circ}$ ). Reales decretos de nombramiento de cuatro magistrados del Tribunal Constitucional (arts. $159.1 \mathrm{CE}, 16$ a 18 de la LOTC y 204 del RC). Puesto que los miembros del Alto Tribunal son nombrados por el Rey (y por tanto por medio de real decreto) a propuesta, un tercio de ellos, del Congreso de los Diputados. $4^{\circ} \%$. Reales decretos de nombramiento de diez vocales del Consejo General del Poder Judicial (arts. 122.3 CE y 112

30 Este mismo término es el que utiliza De LA IglesiA, A., Ob. cit, págs. 148 y 150 principalmente, con un sentido aproximado pero no idéntico al que aquí se da a la expresión.

31 En efecto, existe un supuesto constitucional en el que la decisión concorde del Congreso y del Senado provoca la disolución de ambas Cámaras y la convocatoria de nuevas elecciones generales. Disolución y convocatoria que sólo son posibles por medio de real decreto, firmado por el Rey y refrendado -es de suponerpor el Presidente del Gobierno. Se trata de la aprobación del principio de reforma constitucional del art. 168 CE por dos tercios de ambas Cámaras, es decir, para reformas sustanciales o incluso total del Texto. 
y 113 de la LOPJ). Pues tales vocales son designados igualmente por el Rey a propuesta del Congreso y del Senado en los términos previstos en la LOPJ. El refrendo corresponde aquí al Ministro de Justicia por mandato legal de dudosa constitucionalidad (art. 113 LOPJ) ${ }^{32}$.

c) Del Senado, sólo existen dos casos: $1 .{ }^{\circ}$. Reales decretos de nombramiento de cuatro magistrados del Tribunal Constitucional (arts. 159.1 CE, 16 LOTC y 184 a 186 del RS). Refrenda el Presidente del Gobierno. $2^{\circ}$ ). Reales decretos de nombramiento de diez vocales del Consejo General del Poder Judicial (arts. 122.3 CE,112 y 113 de la LOPJ, Y 187 RS), con el refrendo del Ministro de Justicia (art. 113 LOPJ).

d) Del Presidente del Gobierno. Sólo existen tres supuestos y en todos ellos el Presidente ejerce competencias que la Constitución le otorga exclusivamente a él sin necesidad de que concurra la voluntad del Gobierno, por tratarse de decisiones personales suyas. $1 .{ }^{\circ}$. Reales decretos de nombramiento o de cese de los restantes miembros del Gobierno (arts. 62.e. y $100 \mathrm{CE}$ ) siempre a propuesta y con el refrendo del Presidente (art. 2.2.k. de la LG). 2..$^{\circ}$. Real decreto de disolución anticipada del Congreso, del Senado o de las Cortes Generales y de convocatoria de elecciones a la o las Cámaras legislativas nacionales (art. $115 \mathrm{CE}$ ); puesto que, pese a exigirse la deliberación previa del Consejo de Ministros, la decisión es del Presidente «bajo su exclusiva responsabilidad". $3^{\circ}$ ). Real decreto de convocatoria de referendum ${ }^{33}$. (arts. 62.c y $92 \mathrm{CE})$, siempre con la autorización del Congreso de los Diputa-

32 El art. 64.1 CE menciona como supuesto normal el refrendo de los actos del Rey por el Presidente del Gobierno y en cambio, el de "los Ministros competentes" sólo corresponderá "en su caso", es decir, refrendará un Ministro sólo cuando se trate de materias de su competencia, tal como confirma la reciente Ley del Gobierno: los ministros refrendan»en materias propias de su Departamenton lart. 4.d). Pero el Consejo General del Poder Judicial es un órgano constitucional y por tanto ha de entenderse que los reales decretos que determinan la composición del mismo deben ser refrendados por el Presidente del Gobierno, pues nunca será competencia de un Ministro individual la designación del CGPJ. En todo caso, tratándose de una decisión de otro Poder del Estado, no es lógico que se considere tales decretos como materia de la competencia del Ministro de Justicia. Además, la tendencia clara en el Derecho comparado, especialmente en los sistemas parlamentarios racionalizados es el carácter residual del refrendo de los ministros, correspondiendo al Presidente refrendar toda decisión política general que afecte a varios Departamentos o precise el acuerdo del Consejo de Ministros, como evidentemente ocurre en el caso que analizamos. Cfr. García CANales, M.: Refrendo de los actos del Rey, "Enciclopedia Jurídica Básica». Madrid 1995, Tomo IV, pág. 5.676.

33 Según la Constitución, "El referendum será convocado por el Rey, mediante propuesta del Presidente del Gobierno, previamente autorizada por el Congreso de los Diputados" (art. 92.2), sin embargo, la Ley Orgánica 2/1980, de 18 de 
dos. Con respecto a estos tres supuestos es conveniente recordar que la figura de los "reales decretos presidenciales", esto es, los que dicta el Rey a propuesta del Presidente del Gobierno sin que haya intervenido el Consejo de Ministros, han recibido carta de naturaleza legal muy recientemente, en la Ley 50/1997, de 27 de noviembre (art. 25) ${ }^{34}$.

e) Del Gobierno. Es lo más frecuente, puesto que el art. 62.f. CE atribuye al Rey la función de uexpedir los decretos acordados en Consejo de Ministros», por lo que toda decisión política del Gobierno deberá siempre aprobarse con forma de real decreto. Entrarian aquí todos los reales decretos que aprueban los siguientes actos constitucionales: $1^{\circ} \%$. Real decreto de declaración, prórroga o levantamiento del estado de alarma (art. 116.2 CE), teniendo presente que la prórroga precisa la autorización previa del Congreso de los Diputados. $2 .^{\circ}$ ). Real decreto de declaración, prórroga o levantamiento del estado de excepción (art. 116.3 CE), en todo caso con autorización previa del Congreso. $\left.3^{\circ}\right)$. Reales decretos de nombramiento de dos magistrados del Tribunal Constitucional (art. 159.1 CE y concordantes de la LOTC). 4. ${ }^{\circ}$. Real decreto de utilización de la potestad excepcional de compulsión sobre las Comunidades Autónomas del art. 155 CE, con la aprobación de la mayoría absoluta del Senado y tras ser desoído el requerimiento al Presidente de la Comunidad afectada.

enero, reguladora de las distintas modalidades de referendum, precisa que "Corresponde al Rey convocar a referendum, mediante Real decreto acordado en Consejo de Ministros y refrendado por su Presidente" (art. 2.3). De tal manera se ha identificado la voluntad del Gobierno con la de su Presidente, que la decisión no correspondería a la exclusiva competencia de éste sino a la decisión colegiada del Consejo de Ministros. La reciente Ley del Gobierno, en cambio, precisa como función del Presidente y no del Gobierno el proponer al Rey la convocatoria de referendum consultivo (art. 2.2.e) recordando la necesaria autorización del Congreso de los Diputados, pero omitiendo la deliberación previa del Consejo de Ministros.

34 Esta figura de los «decretos presidenciales» no ha sido suficientemente estudiada. Véase su aparición y reaparición en distintos momentos de la Historia constitucional de España en DE LA IGLESIA, A.: Ob. Cit.. Su reciente incorporación al Ordenamiento español, primero de forma anómala en las leyes de acompañamiento de la Ley de Presupuestos Generales del Estado y ahora en la Ley del Gobierno merecen un estudio en profundidad que apenas ha empezado a realizarse. Con todo, merecen consultarse los trabajos de LóPEZ CALVO, J.: Organización y funcionamiento del Gobierno, Madrid 1996, págs. 375 a 377 y PAREJo Alfonso (ed.): Estudios sobre el Gobierno. Seminario sobre el proyecto de ley reguladora del Gobierno, Madrid 1996. Con posterioridad a la aprobación de la Ley, el número monográfico sobre «El Gobierno y la Administración» de Documentación Administrativa, y en concreto Garcia FERNÁNDEZ, J.: El funcionamiento y la acción del Gobierno en el Titulo III de la Ley del Gobierno, especialmente las págs. 133 a 136. 
f) Del Tribunal Constitucional. Solamente existe un real decreto de este tipo: el de nombramiento del Presidente del Tribunal Constitucional (art. 160 CE y 9 LOTC) ${ }^{35}$.

g) Del Consejo General del Poder Judicial. Hay dos supuestos: 1.\%. Real decreto de nombramiento de Presidente del Tribunal Supremo y del propio Consejo General del Poder Judicial (arts. 123.2 CE y 123 de la LOPJ) ${ }^{36} .^{\circ}$ \%. Reales decretos de nombramiento de dos magistrados del Tribunal Constitucional (arts. 159.1 CE y 107.2 y 127.2 de la LOPJ).

h) De las Asamblea legislativas de las Comunidades Autónomas. Exclusivamente un caso: el real decreto de nombramiento de Presidente de la Comunidad Autónoma (art. 152.1 CE y preceptos correlativos de los Estatutos de Autonomía).

Respecto de todos estos reales decretos, por ser actos complejos pueden distinguirse dos fases (a veces más): la propuesta al Rey y el propio acto regio. Pues bien, todos los actos simples necesarios para la emisión de tales actos complejos tienen la consideración de actos constitucionales. ${ }^{37}$ Así, por ejemplo, son actos constitucionales la propuesta del Gobierno al Congreso para que le autorice a declarar el estado de excepción, el acuerdo del Congreso autorizándolo en términos concretos y el real decreto declarando el estado de excepción.

2. ${ }^{\circ}$ Actos constitucionales parlamentarios. Existen numerosas decisiones políticas singulares de las Cámaras, sobre todo del Congreso de los Diputados, que no se aprueban con forma de ley y sin embargo o bien afectan vitalmente al proceso politico o tienen una eficacia similar a una ley sin serlo. Ante todo, algunos de los regulados en el Título II de la Constitución, referentes a la persona del Rey o de quienes pueden llegar a serlo: proveer a la sucesión una vez extinguidas las

35 Igualmente debe considerarse un acto constitucional el nombramiento del Vicepresidente, pues aunque la Constitución ni tan siquiera lo menciona, su función, tal como queda regulada la figura en la LOTC no deja lugar a dudas sobre la naturaleza de su nombramiento.

36 Con el nombramiento del Vicepresidente de este órgano constitucional sucede lo mismo que en el caso anterior (art. 124 LOPJ).

${ }_{37}$ El Tribunal Constitucional manifestó con respecto al nombramiento de Presidente de la Comunidad Foral de Navarra que se trata de un «acto compuesto de nombramiento, el cual comprende cada uno de los que lo forman, ha de incluirse en su conjunto y en cada una de sus partes dentro de la materia constitucional» (STC 16/1984, FJ $4 .^{\circ}$ \% Sin embargo no todos los actos de trámite previstos en la Constitución deben considerarse como actos constitucionales. No lo sería, por ejemplo, la remisión de un proyecto de ley por el Gobierno al Congreso (art. 88 CE). 
lineas Ilamadas en Derecho (art. 57.3), prohibir matrimonio al heredero de la Corona (art. 57.4), reconocer la inhabilitación regia (art. 59.2), nombrar la Regencia (59.3) y nombrar tutor al Rey menor de edad (art. 60.1). También es un acto constitucional la autorización al Rey para declarar la guerra o hacer la paz (art. 63.3). Por otro lado, es también evidente que pertenecen a esta categoría diversos actos de relación con el Gobierno (investidura de su Presidente, art. 99, denegación de confianza, art. 112, moción de censura, art. 113) que sin embargo se integran dentro del acto regio complejo de nombramiento del Presidente del Gobierno, y las autorizaciones o declaraciones, según los casos, de los estados de anomalía y su cese (art. 116), la convalidación o no de los decretos-leyes y las autorizaciones para la ratificación de los tratados del art. 94.1 CE. La designación de sus propios órganos rectores (art. 72.2) y del Defensor del Pueblo (art. 54) son otros tantos actos constitucionales. Igualmente, la apreciación de la necesidad de que se dicte una ley armonizadora (art. 150.3 CE) ${ }^{38}$.

3. ${ }^{\circ}$ Actos constitucionales de las Comunidades autónomas. Ya hemos visto que la propuesta de Presidente de la Comunidad que hace la Asamblea al Rey es un acto constitucional simple que se integra en el acto regio de nombramiento del mismo. Hay que añadir entonces los decretos de disolución de la Asamblea respectiva y de convocatoria de elecciones autonómicas y los decretos de designación de los restantes miembros del Gobierno autonómico, ambos dictados por el Presidente de la Comunidad Autónoma.

\section{Según su contenido}

Como hemos podido ver hasta ahora, los actos constitucionales versan sobre designación de personas, sobre períodos excepcionales o sobre validez de normas.

$\left.1 .^{\circ}\right)$ Son del primer tipo todos los actos constitucionales dirigidos a determinar las personas que han de ocupar un cargo superior en el Estado. Ya vimos que esto sucede generalmente por medio de real

38 La creación de una Comisión de investigación, así como la propia aprobación por el Pleno de las conclusiones a las que pueda llegar una de ellas, no suelen tener, en principio, efectos jurídicos directos externos, pero cuando los tengan (vg. cuando dé lugar a una actuación judicial contra quien se negó a acudir al ser citado por la Comisión, art. 76.2 CE y LO 5/1984, de 24 de mayo), entonces si sería un acto constitucional parlamentario conforme a la definición propuesta. 
decreto, pero sin olvidar que algunos cargos designados por el Parlamento no son nombrados por el Rey, por ejemplo, los propios órganos rectores de las Cámaras o el Defensor del Pueblo.

2. ) Son actos constitucionales que afectan a períodos excepcionales los que producen la pérdida temporal de vigencia de garantías constitucionales, tanto de las libertades (art. $116 \mathrm{CE}$ ) como de la autonomía política de las Comunidades autónomas (art. $155 \mathrm{CE}$ ).

3..$^{\circ}$ Son actos constitucionales sobre validez de normas los que sirven para autorizarlas (los tratados internacionales del art. 94.1 CE), para convalidarlas (los decretos-leyes, art. $86 \mathrm{CE}$ ), para permitirlas (la necesidad de que se dicte una ley armonizadora, art. 150.3 CE) o para ratificarlas (el referendum nacional, al menos el de reforma constitucional, arts. 167.3 y $168.3 \mathrm{CE})$.

\section{Según su eficacia}

De acuerdo con este criterio de clasificación, podemos distinguir entre aquellos actos constitucionales que tienen eficacia constitucional complementaria y aquellos que tienen eficacia legislativa.

$\left.1 .^{\circ}\right)$ Tienen eficacia constitucional complementaria todos los actos constitucionales que resultan absolutamente imprescindibles para la efectividad de los preceptos constitucionales que atribuyen funciones y potestades. Asi, todos los actos constitucionales de designación de personas y los de períodos excepcionales entran en este grupo: los primeros porque la designación de la persona que ha de ocupar el cargo superior de gobierno es necesaria para que tal órgano pueda ejercer sus funciones constitucionales. Los últimos porque el precepto constitucional que autoriza la suspensión temporal de otros nunca tendría efectividad si no se dicta tal acto constitucional ${ }^{39}, y$ además por otra razón, porque dejan en suspenso temporalmente normas constitucionales que se ven durante ese período excepcional sustituidas por otras normas distintas ${ }^{40}$.

39 Por supuesto, entran aquí también los referenda sobre reforma constitucional, que no tendrian eficacia constitucional complementaria, sino plena y absoluta.

40 En este sentido no debe considerarse que el estado de alarma tenga una naturaleza distinta al de excepción y el de sitio. Es cierto que durante su vigencia no se pueden suspender derechos fundamentales constitucionalmente garantizados, pero sí que se modifica el estatus básico del ciudadano y ello por dos razones: 
2.9) Tienen eficacia legislativa los actos constitucionales que dan vigencia (o permiten que la tengan) a normas con rango de ley, tales como la convalidación de los decretos-leyes y la autorización de los tratados internacionales del art. 94.1 CE.

\section{Según su forma}

La casi totalidad de los actos constitucionales revisten la forma de real decreto o de "acuerdo" o "resolución" parlamentaria o de otro órgano constitucional.

1.') Revisten forma de real decreto los actos constitucionales formalmente regios, aunque paradójicamente pueden carecer de forma jurídica los escasísimos actos constitucionales estrictamente regios que la Constitución contempla: el nombramiento de tutor del heredero menor de edad en el testamento del Rey (art. 60.1 CE) y la prohibición para contraer matrimonio a quien tenga derecho a sucederle en el trono (art. $57.4 \mathrm{CE})^{41}$. En el caso de los Presidentes de las Comunidades autónomas, el único acto constitucional que le compete, la disolución de su Asamblea, se realiza por decreto autonómico, que obviamente no es "real» por carecer de la firma regia.

2..$^{\circ}$ Los demás actos constitucionales revisten la forma de "acuerdo" del órgano colegiado que lo dicta, normalmente las Cámaras, y en algún caso de propuesta al Rey, el Consejo General del Poder Judicial y el Tribunal Constitucional.

\section{Según su naturaleza}

Aunque por definición los actos constitucionales no son normas sino precisamente actos singulares, podemos distinguir entre aquellos

primera, porque se pueden limitar, si no suspender, algunos derechos fundamentales y segunda porque pueden imponerse deberes y prestaciones personales no exigibles fuera de tales situaciones (art. 30.4 CE). Defendí esta postura contraria a la opinión mayoritaria de la doctrina en otro trabajo: El estado de alarma y su ambigua naturaleza, "Cuadernos constitucionales de la Cátedra Fadrique Furió Ceriol", n. ${ }^{\circ} 8$ (1994), especialmente, págs. 104 y s.

41 Por las razones que posteriormente se expondrán, los reales decretos de nombramiento y cese de los miembros civiles y militares de la Casa del Rey no son actos constitucionales, sino actos administrativos o si se prefiere meramente políticos. 
que contienen exclusivamente un acto concreto y los que además incluyen algún tipo de regulación que pudiera considerarse como norma.

1. ${ }^{\circ}$ Todos los actos de designación de personas son en principio del primer tipo. También lo son los de validez de normas. Su contenido es simplemente la determinación del nombre de la persona que ocupará un cargo superior, en el primer caso, o la simple referencia afirmativa a la autorización o convalidación de la norma concreta a que se refiere, en el segundo.

$2^{\circ}$ ) En cambio, los actos constitucionales referidos a situaciones excepcionales tienen, por su propia naturaleza dos contenidos distintos: la decisión de aplicar el precepto constitucional excepcional y, junto a ello, el régimen jurídico que temporalmente ha de aplicarse, una vez suspendidas las garantías por la primera parte del acto decidido.

\section{EL CONTROL JURISDICCIONAL DE LOS ACTOS CONSTITUCIONALES}

\section{1. ¿Control de legalidad o control de constitucionalidad?}

A la hora de analizar las formas y vías para la fiscalización de los actos constitucionales es preciso comenzar por aclarar qué tipo de control jurisdiccional cabe sobre estos actos. Ciertamente la diferencia tiende a diluirse cada vez más por la progresiva implantación del juicio de constitucionalidad que los órganos judiciales ordinarios vienen realizando sobre todo tipo de actos y normas: juicio positivo aplicando normas o negativo inaplicando reglamentos, considerando derogadas leyes preconstitucionales o planteando la cuestión de inconstitucionalidad de leyes postconstitucionales. Especialmente compleja es la distinción cuando los tribunales contencioso-administrativos actúan como garantes de los derechos fundamentales en la vía previa al amparo constitucional del art. 53.2 CE.

Sin embargo, por definición, un acto constitucional está directamente incardinado en la Constitución, no en las leyes. En consecuencia el único juicio que cabe sobre ellos es el de constitucionalidad, nunca el de mera legalidad. Tal afirmación resulta clara en algunos casos: cuando la única normativa aplicable a la emisión del acto está en la propia Constitución. Por ejemplo, el nombramiento de Regente o de tutor al Rey menor de edad por las Cortes Generales, arts. 59.3 y 60.1 CE respectivamente. Ninguna ley, ni siquiera los reglamentos parlamentarios, establecen norma complementaria alguna (al menos espe- 
cífica) al respecto. Es también el caso del real decreto que aplique las medidas de coerción del art. $155 \mathrm{CE}$.

Pero esto no es lo más común. Casi todos los actos constitucionales se ven además regidos, al menos en los aspectos puramente procedimentales, por alguna norma legal. Baste recordar, por ejemplo, que el real decreto de disolución de las Cortes y convocatoria de elecciones aparece estrictamente regulado en la LOREG (art. 167) y que la declaración de los estados de anomalía del art. 116 CE debe respetar no sólo los límites constitucionales sino también los previstos en la LOREAES de 1981. Además, en la emisión de la casi totalidad de los actos constitucionales deberán respetarse las normas sobre formación de la voluntad del órgano colegiado que adopta la decisión, sobre todo el Reglamento parlamentario.

Incluso, en el caso extremo en que un acto constitucional no aparece expresamente normado por la Constitución sino por los Estatutos de autonomía, como sucede con el procedimiento de designación de Presidente de una Comunidad autónoma, el Tribunal Constitucional llegó a manifestar lo siguiente: "el Tribunal no puede compartir la tesis de que la cuestión planteada sea de mera legalidad, ya que transciende de la misma para incidir en el orden constitucional $"{ }^{42}$. O lo que es lo mismo: es un juicio de constitucionalidad y no de legalidad el que sobre tal designación se realiza.

Pero aún en estos casos no debemos perder de vista el punto de partida: se trata de actos constitucionales porque están directamente incardinados en la Constitución o al menos en el bloque de constitucionalidad, por lo que seria contradictorio efectuar sobre ellos un juicio de mera legalidad, aun en el caso de que la Constitución se haya limitado a marcar las lineas fundamentales en la normación de ese acto $y$ sea una ley la que desarrolle detalladamente esos principios. No deja por ello de ser un acto estrictamente constitucional. Diremos entonces que el parámetro de enjuiciamiento de la constitucionalidad de tales actos es, además de la propia Constitución, determinado precepto legal que la desarrolla en este punto. Es decir, para ese acto concreto, la norma legal forma parte del bloque de constitucionalidad, en cuanto que ese acto seria inconstitucional si se dictara sin respetar dicha norma. Este fenómeno está ya tan admitido que nadie se extraña de que una verdadera ley pueda ser declarada inconstitucional (y no antiestatutaria) por no respetar el orden de competencias establecido en 
la Constitución y los estatutos de autonomía (art. 28.1 LOTC) o por pretender modificar un precepto contenido en un tratado internacional (art. 96.1 CE). Nadie duda que en todos estos casos se realiza un control de constitucionalidad estrictamente hablando y no un control de mera legalidad. $Y$ el propio Tribunal Constitucional ha ampliado expresamente en varias ocasiones el bloque de normas que sirven de parámetro de enjuiciamiento de la constitucionalidad de las leyes, pues junto a las previstas en el art. 28.1 LOTC, hay que incluir los reglamentos parlamentarios ${ }^{43} \mathrm{e}$ incluso leyes orgánicas concretas ${ }^{44}$. Es evidente, por lo demás, que la propia LOTC actúa como parámetro de constitucionalidad de las demás, aun de las que acabamos de mencionar como integrantes del bloque de constitucionalidad.

¿Y en qué consiste ese juicio de constitucionalidad cuando en lugar de una norma es un acto singular lo que se enjuicia? No cabe duda que los mismos vicios de inconstitucionalidad en que puede incurrir una norma (vicios de procedimiento, de competencia o de contenido material) pueden suceder en un acto constitucional. Así, por ejemplo, el real decreto de nombramiento de un vocal del Consejo General del Poder Judicial seria inconstitucional por vicio de procedimiento si la propuesta no hubiere contado con el respaldo de $3 / 5$ de la Cámara correspondiente (art. 122.3 CE) o si no se hubiese seguido el procedimiento de selección previsto en el reglamento parlamentario (arts. 204 RC , arts. 184 y 187 RS); sería inconstitucional por vicio de competencia si no hubiesen sido propuestos diez vocales por el Congreso y los otros diez por el Senado (inconstitucional y no ilegal, pese a ser la LOPJ quien así lo establece interpretando forzadamente el art. $122.3 \mathrm{CE}$ ); y sería inconstitucional por vicio de contenido material si el designado no perteneciera a las categorías de profesionales del Derecho previstas en el art. 122.3 CE y 112 LOPJ o careciese de los requisitos de antigüedad allí mencionados. El juicio de inconstitucionalidad de los actos que analizamos no sería pues de naturaleza distinta al que realizan las Salas del propio Tribunal Constitucional en los procesos de amparo, con la diferencia de que el parámetro de enjuiciamiento no serian exclusivamente los arts. 14 a 29 y 30.2 CE sino todo el Texto constitucional e incluso, cuando sea el caso, las normas con rango legal interpuestas que regulen la emisión del acto constitucional de que se trate.

43 STC 99/1987, FJ $1 .^{\circ}$ y más matizadamente STC 36/1990, FJ 2..

44 Como la LO reguladora de los Cuerpos y Fuerzas de Seguridad, según la STC 25/1993, FJ $1 .^{\circ}$, reiterado posteriormente en las SSTC 49 y 50/1993. 
Por supuesto que el control de constitucionalidad de estos actos consistirá en un juicio sobre la adecuación de los «elementos reglados" del acto a la Constitución, nunca sobre la oportunidad política del mismo. Ciertamente esta cuestión es mucho más compleja de lo que a simple vista puede parecer, y no cabe duda de que la actual incertidumbre en torno a la posibilidad real de impugnar jurisdiccionalmente los actos constitucionales tiene bastante que ver con ello. Como se trata de decisiones estrictamente políticas que han sido hasta hace muy poco soberanas (y que aun hoy podemos considerar como "cuasisoberanas") existe un temor muy extendido, no sólo entre los agentes políticos, sino en la propia doctrina, de que la posibilidad de controlar jurisdiccionalmente el sometimiento de estos actos al Derecho pudiera suponer dejar en manos de los tribunales competentes (luego veremos cuáles son) la última palabra en decisiones vitales para el proceso político. Piénsese, sobre todo en los actos constitucionales de períodos de excepción y de validez de normas. ¿Puede acaso dejarse en manos de un órgano jurisdiccional, aunque sea el Tribunal Constitucional, la posibilidad de anular la declaración de un estado de anomalía de los previstos en el art. $116 \mathrm{CE}$ por entender que no concurrían las circunstancias que justificaban su declaración? Sucede en estos casos algo análogo al supuesto de control por el Tribunal Constitucional de la oportunidad política de los decretos-leyes. También respecto de los actos constitucionales cabe decir que «en principio y con el razonable margen de discrecionalidad" corresponde a los órganos políticos determinar la conveniencia, la oportunidad o la necesidad del acto, sin perjuicio de que el órgano jurisdiccional, «en base a criterios estrictamente jurídico-constitucionales ${ }^{45}$ pueda considerar la existencia de un abuso manifiesto de las facultades constitucionalmente reconocidas al órgano que produjo el acto en cuestión. Piénsese, por ejemplo, en la utilización de las potestades de intervención excepcional en las Comunidades autónomas del art. $155 \mathrm{CE}$ con fines políticos distintos de los allí previstos.

\section{Fiscalización por los tribunales contencioso-administrativos}

Tres aspectos debemos analizar aquí: la postura que vienen siguiendo los tribunales contencioso-administrativos - particularmente la Sala 3. ${ }^{\mathrm{a}}$ del Tribunal Supremo- cuando han sido impugnados ante ellos 
diversos actos constitucionales, la doctrina del Tribunal Constitucional sobre la posición que al respecto ha ido adoptando el Tribunal Supremo y por último, los cambios que en esta materia va a traer consigo la nueva LJCA.

A) Con respecto a lo primero, la ausencia de una doctrina sobre la categoría de los actos constitucionales como actos jurídico-públicos distintos de las normas y de los actos administrativos ha llevado en los últimos años a situaciones confusas y a veces paradójicas en que los tribunales del orden contencioso-administrativo, fundamentalmente el Tribunal Supremo, no han sabido cómo tratar las impugnaciones de este tipo de actos.

De acuerdo con la normativa legal hasta ahora vigente en desarrollo de los mandatos constitucionales al respecto (principalmente los arts. 24, 53.2 y $106 \mathrm{CE}$ ), la jurisdicción contencioso-administrativa era competente para conocer de las pretensiones que se dedujeran en relación con los actos de la Administración pública sujetos al Derecho administrativo y con las normas de categoría inferior a la ley (art. 1.1.

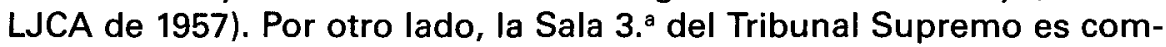
petente para conocer en única instancia de los recursos contenciosoadministrativos que se produzcan contra actos y disposiciones emanadas del Consejo de Ministros, del Consejo General del Poder Judicial y de los órganos de Gobierno del Congreso, del Senado, del Tribunal Constitucional, del Tribunal de Cuentas y del Defensor del Pueblo "en materias de personal y actos de administración" (art. 58.1 LOPJ). Según esto, ninguno de los actos constitucionales está sujeto, por definición, a control jurisdiccional contencioso-administrativo: ni son actos administrativos, ni emanan de ninguna Administración pública, sino del Rey o de las Cámaras, ni son normas de ninguna categoría. $Y$ esto incluso en los casos en que los tribunales contencioso-administrativos actúan como jueces de constitucionalidad, es decir, en el recurso jurisdiccional previo al amparo constitucional, como claramente se deduce del art. 6 de la Ley 62/1978, de de 26 de diciembre.

Sin embargo, a causa del progresivo abandono de la doctrina de los actos políticos como actos no fiscalizables y de su confusión con los actos constitucionales en sentido estricto se han producido algunos casos en que se ha pretendido que fuera el Tribunal Supremo quien controlara la constitucionalidad de algún acto constitucional concreto. A esta situación ha contribuido además la ampliación del control jurisdiccional contencioso a la actividad materialmente administrativa de otros órganos constitucionales: del Tribunal Constitucional, del Consejo General del Poder Judicial, o de los propios órganos de gobierno de 
las Cámaras parlamentarias (art. 58.1 LOPJ). Se ha llegado así a reconocer la existencia de uactos políticos» de las Cámaras junto a los actos políticos del Gobierno. La confusión al respecto ha sido y es, por tanto, considerable.

Es sabido que en los años que siguieron a la entrada en vigor de la Constitución, la categoría de los "actos políticos» del art. 2.b LJCA sirvió como excusa para evitar al Tribunal Supremo la engorrosa y comprometida tarea de enjuiciar la constitucionalidad de aquellos pocos actos constitucionales que ante él fueron impugnados.

Así, en 1982 se presentó por un particular un recurso contra el real decreto de disolución de las Cortes Generales y convocatoria de elecciones, siendo considerado por el Abogado del Estado y, al parecer, por el propio Tribunal Supremo, como una norma de rango reglamentario pero no sujeta al Derecho administrativo: «es patente que su contenido desborda lo que viene comúnmente definido como acto de la Administración Pública sujeto a Derecho administrativo, lo que ... nos sitúa en la previsión del art. 82.a de la misma Ley" (incompetencia de jurisdicción) por lo que se acordó la inadmisión del recurso $0^{46}$. Por cierto que años después fue impugnado otro real decreto de disolución de las Cortes y convocatoria de elecciones generales, siendo expresamente considerado por el Tribunal Supremo como norma de rango reglamentario ${ }^{47}$.

Después, no habiéndose impugnado directamente actos constitucionales, sino actos meramente políticos, el Tribunal Supremo fue asumiendo la posición defendida mayoritariamente por la doctrina administrativista ${ }^{48}$ de entender que la Constitución había derogado la ex-

46 STS, de 24 de septiembre de 1984 , Sala 3. ${ }^{a}$, Conss. $1 .^{\circ}$ y $2 .^{\circ}$.

47 Esta última resolución no he podido localizarla, pues aparece citada en la STS de 15 de julio de 1997 (Sala 3. a, Sección 6. ${ }^{a}$, RA 5640), FD 3. ${ }^{\circ}$ d)como «ATS de 31 de mayo 1993 (Sala 3. ${ }^{a}$, Sección 7. ${ }^{a}$, RA 4.001)" Sin embargo, dicho ATS no tiene nada que ver con este tema.

48 Véase por todos Garcia de Enterria, E. y Fernández, T.R. Curso de Derecho administrativo I, Madrid, 5. Edición de 1989, págs. 558 y ss. Por su parte, A. GualTA afirma rotundamente que "no debe haber, no puede haber y no hay ningún acto jurídico estatal que escape a la posibilidad de fiscalización jurisdiccional ulterior" (Recurso de amparo contra actos sin fuerza de ley, "RCG", n. 7 , 1986, pág. 175). Lo cual es muy loable y además constituye el punto de partida de la teoria de los actos constitucionales, pero tal afirmación es muy peligrosa si no se deslindan los campos propios del Tribunal Constitucional y del Poder Judicial. Por eso considero más acertada la postura de L. López Guerra que, junto a la proclamación de la plenitud de control jurisdiccional, advierte enseguida de que no todo corresponde en este campo a la jurisdicción contencioso-administrativa. Cfr. La posición constitucional del Gobierno, en "El Gobierno y la Administración en la Constitución», Tomo I, 
cepción del art. 2.b de la LJCA y por tanto entró a enjuiciar la legalidad de tales actos, si bien todavía en 1992 se aceptó la permanencia de la doctrina de los actos políticos no fiscalizables, aunque ya de forma muy restrictiva ${ }^{49}$ con base en la Sentencia del Tribunal Constitucional de 15 de marzo de 1990 que después se analizará.

Pero ese mismo año 1992, el Gobierno nombró como Fiscal General del Estado a quien, según varias asociaciones de jueces $y$ de fiscales, no reunía los requisitos legales para ello. Es de advertir que el real decreto de nombramiento de Fiscal General del Estado se encuentra en la frontera misma entre los actos constitucionales y los actos meramente políticos, aunque, por las razones que luego veremos, debe considerarse como acto político simple. Aquí el Tribunal Supremo sentó la doctrina que después ha mantenido y que inspira la nueva LJCA: reconoce la existencia objetiva de actos de dirección política del Gobierno en principio inmunes al control jurisdiccional de legalidad, pero para dar cumplimiento a los arts 9 y 24.1 de la Constitución, dicho control deberá realizarse cuando "el legislador haya definido mediante conceptos judicialmente asequibles los límites o requisitos previos a los que deben sujetarse dichos actos de dirección política, en cuyo supuesto los Tribunales debemos aceptar el examen de las eventuales extralimitaciones o incumplimientos de los requisitos previos en que el Gobierno hubiera podido incurrir al tomar la decisión ${ }^{50}$. En esto consisten precisamente los elementos reglados del acto jurídico-público: en los "conceptos judicialmente asequibles" previstos en las normas (de cualquier rango). En el caso presente, el motivo de impugnación del nombramiento era que el designado como Fiscal General del Estado no reunía los requisitos exigidos en el art. 29.1 del Estatuto Orgánico del Ministerio Fiscal («jurista de reconocido prestigio con más de quince años de ejercicio efectivo de su profesión»), porque el Gobierno había computado para ello los años en que ocupó el puesto de Gobernador Civil. El Tribunal Supremo entendió que tales años no eran computables por no ser jurídica tal profesión (Fundamento de Derecho

Madrid 1988, pág. 26. Dicho en otros términos: contra lo que comunmente se opina y contra la opción tomada por la nueva LJCA no hay dificultad alguna en reconocer que existen actos jurídico-públicos exentos de control por los tribunales contencioso-administrativos por razón de la materia constitucional sobre la que versan. Lo que se defiende en las lineas que siguen es que tal es el caso de los actos constitucionales $y$ sólo de ellos y que su control jurisdiccional debe quedar reservado en exclusiva al Tribunal Constitucional y precisamente actuando en Pleno.

49 STS de 1 de diciembre de 1992 (Sala 3. ${ }^{a}$, Sección 7. ${ }^{a}$, FD $2 .^{\circ}$ de la Sentencia apelada, aceptado expresamente por el TS en el FD $1 . \%$.

50 STS de 28 de junio de 1994 (Sala 3. en Pleno), FD 1. ${ }^{\circ}$. 
$\left.6 .^{\circ}\right)$ y en consecuencia declaró nulo el Real decreto. Es de notar que la Constitución no exige tal requisito (art. 124.4 CE) que ha sido pues introducido por la ley.

Sin embargo, unos años antes, en el Real decreto 1882/1985 de 16 de octubre, a propuesta del Senado, el Rey nombró, como vocal del Consejo General del Poder Judicial a una persona a quien se hubo que computar los años de pasantía (¿acreditables en documento público?) para alcanzar los quince de ejercicio de su profesión como jurista de reconocido prestigio, tal como exige, esta vez, la propia Constitución (art. 122.3). Ahora bien, con independencia de la cuestión de fondo ¿cuál habría sido la actitud del Tribunal Supremo si tal Real decreto hubiese sido impugnado? ¿Ejercería entonces éste un control -de constitucionalidad y no ya de legalidad- si se impugnara un real decreto similar? La confusión estriba en que se olvida que no todos los reales decretos son actos del Gobierno, puesto que algunos son actos del Rey y precisamente actos constitucionales. En todo caso habría resultado asombroso que un tribunal contencioso-administrativo hubiera considerado nula por inconstitucional una decisión del Senado, adoptada además por mayoría de 3/5, y formalizada por el Rey.

Por eso no es tampoco aceptable la doctrina defendida en el voto particular de la última Sentencia mencionada en la que, alegando que se trata de un "acto constitucional" (sic, en realidad no lo es) considera que no cabe control jurisdiccional alguno, sino sólo control político ante el Parlamento. Si semejante doctrina se aplicara al real decreto de nombramiento de vocales del Consejo General del Poder Judicial, por ejemplo, (que sí son actos constitucionales en el sentido estricto que aquí se da a la expresión), serían las Cámaras quienes controlarían su propio respeto al art. $\mathbf{1 2 2 . 3}$ de la Constitución al proponer al Rey los nombres de los vocales del Consejo, lo que no dejaría de ser un serio paso atrás en el proceso de sometimiento al Ordenamiento de todos los poderes constituidos, incluido el legislativo.

Sentencias posteriores del Tribunal Supremo han confirmado y aclarado la doctrina de los "conceptos judicialmente asequibles» como objeto de control jurisdiccional contencioso-administrativo en los actos políticos del Gobierno, a los que se caracteriza por ser "expresión del mayor grado de discrecionalidad y oportunidad" política ${ }^{51 .}$

51 STS de 15 de julio de 1997 (Sala 3. ${ }^{a}$, Sección $6 .^{\circ}$, FD 3. ${ }^{\circ}$ E). Ultimamente se ha llegado al extremo de considerar como "concepto judicialmente asequible" nada menos que las causas que motivaron la aprobación de una moción de censura en un Ayuntamiento. Ciertamente, las corporaciones locales, con autonomía 
Pero siguiendo esa misma linea se ha llegado a anular la sentencia de un Tribunal Superior de Justicia que se negó a enjuiciar sobre la validez del decreto autonómico de disolución de la Asamblea y convocatoria de elecciones: sería, según el Tribunal Supremo, un acto político $y$ por tanto deben ser enjuiciados los elementos reglados del mismo ${ }^{52}$. Lo que sucede es que, por las razones que más abajo expondremos, el decreto de disolución de un parlamento autonómico no es un acto político simple, sino un acto constitucional. Permitir que sea controlado jurisdiccionalmente por un Tribunal Superior de Justicia equivale a considerar como autonomía meramente administrativa a la de una Comunidad autónoma.

B) Con respecto a la posición adoptada en este tema por el Tribunal Constitucional, quedó fijada en la Sentencia 45/1990 y fue reiterada en otras posteriores de ese mismo año y del siguiente (SSTC $196 / 1990$ y 220/1991). En definitiva, el Tribunal considera, siguiendo una importante corriente doctrinal ${ }^{53}$, que existen ciertas materias estrictamente políticas (y pone como ejemplo las de relación con otros poderes del Estado) en que la actuación del Gobierno no está sujeta al Derecho administrativo y por tanto no constituye lesión del art. 24 CE la

puramente administrativa (art. $140 \mathrm{CE}$ ) no pueden dictar «actos políticos», pero tan peligrosa ampliación de las potestades jurisdiccionales de control sobre los órganos públicos podría ser utilizada en el futuro por el Tribunal Constitucional para anular una moción de censura aprobada por el Congreso (o a nivel autonómico por una Asamblea parlamentaria) por considerar que la motivación de los diputados que votaron a favor de la censura no era la que, presumiblemente, prevé la norma constitucional o el reglamento parlamentario. (STS de 26 de mayo de 1997, Sala 3. ${ }^{\text {, }}$ Sección 7.a).

52 STS de 15 de julio de 1997, Sala 3. ${ }^{a}$, Sección 6. ${ }^{a}$. En esta resolución se hace un estudio minucioso y completo de la evolución jurisprudencial en materia de fiscalización de los actos políticos (FFDD $3 .^{\circ}$ y $\left.4 .^{\circ}\right)$. Son también muy interesantes al respecto las dos SSTS de 4 de abril de 1997 (Sala 3. ${ }^{a}$ en Pleno) dictadas en relación con la desclasificación de documentos secretos del CESID.

53 Así, F. Garrido Falla Tratado de Derecho administrativo, Volumen I, 11. ${ }^{\text {a }}$ Edición, Madrid 1989, pág. 385. Este autor, en el comentario al art. 97 de la Constitución de los Comentarios a la Constitución por él dirigidos, 2. ${ }^{a}$ Edición, Madrid 1985, pág. 1371 llega a intuir los actos constitucionales: "cosa distinta ocurre cuando nos enfrentamos con los auténticos actos politicos que configura la Constitución, es decir, con los que atañen a las relaciones entre Poderes. Aquí la exclusión lo es por definición"... "Como ejemplo clave se podría citar lo dispuesto en el art. 115.2 de la Constitución: 'la propuesta de disolución no podrá presentarse cuando esté en trámite una moción de censura' ¿Qué ocurre si se infringe este precepto y la disolución se realiza? No hay duda de que una tal actuación abre un conflicto político-constitucional; tampoco lo hay de que el decreto de disolución no sería impugnable en vía contencioso-administrativa». 
inadmisión de recursos contencioso-administrativos en tales materias. Lo curioso es que en los tres casos se trataba de actos meramente políticos y no de actos verdaderamente constitucionales. Es decir, precisamente de actos que quedan sujetos a control jurisdiccional ordinario en la nueva LJCA.

Por lo demás, tampoco el Tribunal Constitucional ha sabido hasta hoy distinguir entre los actos constitucionales y los meramente políticos, aunque en el caso de la propuesta de nombramiento de un Presidente de Comunidad Autónoma impugnada por el Presidente del Gobierno por la vía del art. 161.2 CE y contra la que se presentó además un recurso de amparo, se consideró acertada la inhibición de los tribunales ordinarios por tratarse de "materia constitucional». Por otro lado, la admisión a trámite de la impugnación y del recurso de amparo, evidencian que lo consideró un acto sin valor del ley. En definitiva, para el Tribunal Constitucional no todo acto singular de los poderes públicos está sujeto a Derecho administrativo, por lo que existen actos jurídicopúblicos singulares y concretos que no son actos administrativos ni están, en consecuencia, sujetos al control jurisdiccional por los tribunales ordinarios y si al de las Salas del Tribunal Constitucional en los recursos de amparo. Sin embargo, tal categoría de actos englobaría lo que aqui llamamos actos constitucionales con los actos meramente políticos, justo cuando estos últimos desaparecen de nuestro Ordenamiento jurídico.

C) Con respecto a las modificaciones que en esta materia va a traer consigo la nueva LJCA debemos aclarar lo siguiente. La solución que se ha dado a este problema no ha sido, desde luego, acertada. Es verdad que se ha producido un importante salto cualitativo al hacer desaparecer definitivamente la excepción de los actos políticos como no fiscalizables por los tribunales contencioso-administrativos, excepción que aún mantenía el Proyecto de 199454; pero, al no establecer previa-

54 En dicho Proyecto se aceptaba la doctrina del Tribunal Constitucional y se mantenía por tanto la excepción de los actos políticos aunque reducidos a "los actos del Gobierno y de los Consejos de Gobierno de las Comunidades Autónomas que se refieran a sus relaciones con otros órganos constitucionales y estatutarios y los dictados en ejercicio de la función de dirección de la política interior y exterior" (art. 3.c). Tal precepto habría dejado las cosas como estaban e incurria en defectos importantes por su ambigüedad al definir la esfera del acto político y por ignorar que algunos procedian del Presidente del Gobierno y no del Consejo de Ministros, como hizo notar el Consejo de Estado en su informe sobre el Proyecto de Ley. Cfr. Recopilación de doctrina legal, Año 1995, pág. 52. El Informe del CGPJ a dicho Proyecto demuestra la tremenda confusión existente en esta materia. Cfr. Anteproyec- 
mente la distinción entre actos políticos y actos constitucionales, lo único que se ha conseguido es aumentar la confusión al respecto.

La Exposición de motivos asi lo demuestra al afirmar que «la Ley parte del principio de sometimiento pleno de los poderes públicos al ordenamiento jurídico, verdadera cláusula regia del Estado de Derecho. Semejante principio es incompatible con el reconocimiento de cualquier categoria genérica de actos de autoridad-llámense actos políticos, de Gobierno, o de dirección política- excluida "per se" del control jurisdiccional». Hasta aquí nada que objetar. "En realidad el propio concepto de 'acto político' se halla hoy en franca retirada en el Derecho público europeo». Pero a continuación se añade un error mayúsculo: "los intentos encaminados a mantenerlo, ya sea delimitando genéricamente un ámbito en la actuación del Poder Ejecutivo regido sólo por el Derecho constitucional, y exento del control de la Jurisdicción contencioso-administrativa, ya sea estableciendo una lista de supuestos excluidos del control judicial, resultan inadmisibles en un Estado de Derecho". Obsérvese la gravedad del error en el razonamiento: porque no debe quedar exenta de control jurisdiccional ninguna actuación de los poderes públicos, se somete a control judicial ordinario todo acto que proceda del Poder Ejecutivo. Sin embargo, ni toda actuación del Gobierno es administrativa, por ejemplo cuando aprueba normas con rango de ley y cuando propone al Rey un acto constitucional, ni con semejante medida se va a someter toda actuación de los poderes públicos al Derecho, porque la única actividad de los otros poderes del Estado que se sujeta al control judicial ordinario es la materialmente administrativa.

Se ha desnaturalizado así la propia significación constitucional de la jurisdicción contenciosa: al art. 106.1 CE («los tribunales controlan la potestad reglamentaria y la legalidad de la actuación administrativa...") se ha añadido de hecho, la frase "y toda actuación del Gobierno cualquiera que sea su naturaleza»). Y como el Gobierno ejerce funciones evidentemente constitucionales, no administrativas, resulta que corresponde a la jurisdicción contencioso-administrativa el control de legalidad de la actuación administrativa de todos los poderes públi$\cos$ y además, ahora, el control de constitucionalidad y de legalidad, según los casos, de toda actuación que proceda el Gobierno. En efecto, la Sala 3. ${ }^{a}$ del Tribunal Supremo conocerá en única instancia de los

to de Ley reguladora de la jurisdicción contencioso-administrativa e informe del Consejo General del Poder judicial. Cuadernos del CGPJ. Madrid 1995, especialmente las págs. 122 y ss. 
recursos contra actos y disposiciones del Consejo de Ministros (art. 12.1) "cualquiera que fuese la naturaleza de dichos actos" (art. 2.a). Sólo ha faltado someter a control contencioso-administrativo los decretos-leyes y los decretos legislativos para terminar de convertir al Gobierno de órgano constitucional impulsor de la política general en un simple órgano de dirección de la Administración pública.

Según esto, el real decreto de disolución de las Cortes y convocatoria de elecciones generales, el de nombramiento de dos magistrados del Tribunal Constitucional a propuesta del Gobierno, el de convocatoria de referendum consultivo, el de declaración del estado de excepción previamente autorizado por el Congreso y el de intervención excepcional en las Comunidades autónomas del art. 155, por ejemplo, podrán ser impugnados ante la Sala $3 .^{a}$ del Tribunal Supremo. Queda sin embargo por saber, ante la falta de claridad al respecto en la nueva LJCA y en otras anteriores como la reciente Ley del Gobierno, si todo lo que se apruebe bajo la forma de real decreto será considerado, a efectos de control jurisdiccional, como procedente del Gobierno. Porque de ser así, también podrían impugnarse ante la jurisdicción contencioso-administrativa los reales decretos de nombramiento de vocales del CGPJ a propuesta de las Cámaras, de magistrados del Tribunal Constitucional a propuesta del Congreso, del Senado o del CGPJ o de nombramiento de Presidente o Vicepresidente del propio Tribunal Constitucional o del CGPJ. Incluso podría serlo, por qué no, el real decreto de nombramiento de Presidente del Gobierno una vez obtenida la investidura por el Congreso. $Y$ por si el disparate fuera pequeño, los términos amplísimos en que se concibe la legitimación para interponer el recurso (art. 19.1.a. LJCA, "las personas físicas o jurídicas que ostentaren un derecho o interés legítimon) terminan de completar el peligrosísimo cuadro de confusión e incoherencia en que queda el sistema de control jurisdiccional de los actos constitucionales tras la nueva Ley jurisdiccional. ¿Se podrá dar el caso de que el real decreto de nombramiento de Presidente del Gobierno sea impugnado ante la jurisdicción contencioso-administrativa por un particular que dice tener interés legítimo en que no se produzca dicho nombramiento, alegando, por ejemplo, que el Rey no invitó al trámite de consulta previa a la propuesta de candidato al representante de la formación política a la que votó dicho particular?

El fondo de la cuestión está en que no se distingue entre los decretos del Rey y los decretos del Gobierno o de su Presidente. Porque los primeros, que formalizan decisiones políticas tomadas por otros órganos -entre ellos el propio Gobierno o su Presidente-, contienen actos 
constitucionales no simples actos políticos. Es decir, actos directamente normados por la Constitución, sujetos sólo a control de constitucionalidad que no tienen nada que ver con los actos administrativos que dicta el Gobierno como órgano supremo de la Administración del Estado. Es de esperar que la jurisprudencia excluya pronto los decretos regios dictados a propuesta de órganos constitucionales distintos del Gobierno o su Presidente alegando que no son propiamente «actos del Gobierno", pero va a ser difícil que incluso tales reales decretos se vean libres de control contencioso cuando aparezcan implicados los derechos fundamentales (art. 2.a). En todo caso, reales decretos como el de nombramiento o cese de los ministros, de declaración, prórroga o cese de los estados de alarma o excepción o de disolución de las Cortes quedan con la nueva LJCA sin duda alguna dentro del ámbito de los actos impugnables ante la jurisdicción contencioso-administrativa, aunque es de suponer, se corrija por vía legislativa esta posibilidad en cuanto la mayoría parlamentaria se percate de los peligros que ello supondría o cuando de hecho se impugne y tal vez anule uno de estos actos constitucionales.

\section{Fiscalización por el Tribunal Constitucional}

El segundo tema que debemos examinar aquí es el de la posibilidad teórica de que los actos constitucionales sean enjuiciados por el Tribunal Constitucional y la constatación de si, en efecto, se ha producido ya dicho control y por qué vías.

Sin perjuicio de aclaraciones posteriores podemos decir que, de acuerdo con el desarrollo que la LOTC ha dado al art. $161 \mathrm{CE}$, los procesos de inconstitucionalidad se dirigen contra leyes, disposiciones normativas o "actos con fuerza de ley", expresión ésta cuya relación con los actos constitucionales habrá que aclarar más adelante. El recurso de amparo se dirige no sólo contra actos administrativos sino contra cualquier acto parlamentario que no tenga valor de ley. Los conflictos territoriales de competencias podrían abarcar en principio cualquier acto o norma, aunque se ha considerado que sólo puede utilizarse esta vía cuando el acto o norma no tenga rango de ley. Los conflictos constitucionales de atribuciones en cambio pueden referirse a cualquier acto o norma sin límite objetivo alguno. Por último, las impugnaciones del art. 161.2 CE se dirigen contra normas infralegales o actos, se entiende sin fuerza de ley, de las Comunidades Autónomas. 
En conclusión: podrán enjuiciarse mediante el recurso de amparo o por la vía de las impugnaciones del art, 161.2 o los conflictos de competencias entre el Estado y las Comunidades autónomas aquellos actos constitucionales que no tengan valor o fuerza de ley; por contra, la vía del recurso de inconstitucionalidad (o incluso la cuestión, aunque comúnmente se crea lo contrariol o la del conflicto constitucional de atribuciones serviría para enjuiciar la constitucionalidad de los actos constitucionales con fuerza de ley.

De hecho, sin embargo, muy pocos actos constitucionales han sido impugnados ante el Tribunal Constitucional y casi exclusivamente por la vía del amparo constitucional. Así, la ya mencionada STC 16/1984, sobre propuesta de nombramiento de Presidente de la Comunidad Foral de Navarra, que fue impugnada por doble vía: la del art. 161.2 CE y la del recurso de amparo. La simple admisión de ambos demuestra que para el Tribunal Constitucional no está clara la verdadera naturaleza de los actos constitucionales que, ciertamente, no son en absoluto actos administrativos como expresamente aceptaba la citada sentencia respecto del que fue impugnado, sino más bien otro tipo de actos como a continuación veremos.

\section{ACTOS CONSTITUCIONALES Y ACTOS CON FUERZA DE LEY}

El examen de la naturaleza y variedad real de los actos constitucionales nos ha llevado a un punto crucial: el de la relación entre actos constitucionales y actos con fuerza de ley, pues el control jurisdiccional de los primeros va a depender de si pertenecen o no a esta última categoría.

\section{Qué son los «actos con fuerza de ley»}

Es sabido que la expresión no aparece en la Constitución. El recurso de inconstitucionalidad se dirigiría contra "leyes y disposiciones normativas con fuerza de ley" (art. 161.1.a. CE) y la cuestión contra cualquier "norma con rango de ley" (art. $163 \mathrm{CE}$ ). Ambas expresiones deben entenderse equivalentes en la mente del constituyente, como claramente se aprecia cuando el propio art. 161.1.a. añade: "la declaración de inconstitucionalidad de una norma jurídica con rango de ley ..." Por tanto la suma de las leyes (todo tipo de leyes) y las disposiciones normativas con rango de ley (decreto-ley y decreto legislativo fundamentalmente) conformarían la categoría "normas con rango de ley". 
Fue pues la LOTC la que introdujo la expresión "actos con fuerza de ley" en sus arts. 2.1.a. (funciones del Tribunal), 27.2.b. y e. (objeto de los procesos de inconstitucionalidad), 28.1 (parámetro de enjuiciamiento de la constitucionalidad o "bloque de constitucionalidad"), 29.2 (posibilidad de que se plantee la cuestión si el recurso se desestimó por razones de forma), 30 (carácter no suspensivo de la admisión a trámite de un recurso o cuestión de inconstitucionalidad, pero sí de las impugnaciones del art. 161.2 CE), 31, 32.1, 32.2 y 33 (tramitación de los recursos de inconstitucionalidad), y por último, 39.1, 40.1 (efectos de la sentencia). También, se menciona la expresión aproximadamente contraria: "actos sin valor de ley" en el art. 42 sobre el objeto del recurso de amparo.

El problema central es: si tal expresión no existe en el Texto constitucional aprobado el año anterior, ¿por qué se introdujo en la LOTC y a qué se refiere?

1. ${ }^{\circ}$ El análisis del iter legislativo de la LOTC resulta verdaderamente sorprendente. La expresión figuraba ya en el Anteproyecto remitido por el Gobierno al Congreso ${ }^{55}$. Se presentaron en la Cámara baja siete enmiendas solicitando su supresión ${ }^{56}$. Las razones alegadas iban desde la simple "mejora técnica" del proyecto ${ }^{57}$, a la "clara transgresión de los límites constitucionales, indeterminación del concepto -como mínimo polémico- y por la arbitrariedad e inseguridad jurídica que puede originar ${ }^{58}$ hasta llegar incluso al extremo de solicitar la supresión «no existiendo doctrinalmente los actos con fuerza de ley» ${ }^{59}$.

Semejantes argumentos parece debían haber suscitado un debate interesante en torno a lo que el Gobierno (y la Ponencia, que asumió la expresión sin dar explicación alguna en su Informe) entendian por actos con fuerza de ley. Pero ni en fase de Comisión ni en el Pleno pudo aclararse la naturaleza y el contenido de semejante categoría de actos jurídico-públicos. Sólo una de las enmiendas de supresión se mantuvo para ser defendida en el Pleno de la Cámara baja y los argumentos que se dieron en su favor (y los que no se dieron en su contra) sorprenden en extremo. El Sr Roca Junyent, tras defender que era

55 Publicado en el BOCG $C D$ del 24 de mayo de 1979.

56 Enmiendas números 22, 39, 41 y 77 de los Grupo Socialista del Congreso y Socialistas de Cataluña y 145 y 160 de Minoria Catalana. BOCG CD de 7 de julio de 1979.

\footnotetext{
Enmiendas $n .^{\circ} 22$ y 77.

Enmienda n. 145.

Enmienda $n .^{\circ} 41$.
} 
inconstitucional añadir tal expresión a las otras dos contenidas en el art. 161.1.a CE afirmó:

"Desde que hemos empezado la discusión en trámite de Ponencia y de Comisión respecto de lo que es acto con fuerza de ley, no hemos podido conocer por parte de los representantes del partido del Gobierno ni un solo supuesto que haya sido absolutamente claro. Les hemos pedido humildemente, reconociendo nuestra ignorancia, que nos digan qué es un acto con fuerza de ley y nos han dicho exactamente aquello que no se puede decir: 'un acto con fuerza de ley es esto, un acto con fuerza de ley'. Nos interesábamos por conocer algo más, porque lo que habíamos estudiado de jovencitos era que un acto con fuerza de ley, siguiendo la doctrina clásica francesa, es el que permite al coronel en plena guerra decir a sus soldados: 'adelante' y como pensábamos que en este caso esto no tiene que estar sometido al Tribunal Constitucional, creiamos que no era necesaria la incorporación de este concepto. Pero no nos han dicho lo que era ese acto, no nos lo han explicado $y$, por tanto, si es que hay algún ejemplo que no conocemos, ya que ha habido una resistencia total a explicarnos qué quería decir acto con fuerza de ley y a darnos algún ejemplo que nos valiera. Por consiguiente, nosotros nos oponemos, por cuestión procedimental, por cuestión formal y por cuestión de fondo, por no saber lo que es un acto con fuerza de ley, un ejemplo que no se nos ha citado hasta la fecha, al menos, no sabemos si aquí nos lo van a citar ahora y nos van a convencer ${ }^{60}$.

Dudo que el enmendante quedara convencido, pues sus argumentos tuvieron, tanto en Comisión como en el Pleno, la callada por respuesta: no se contestó nada ni volvió a suscitarse el tema en el resto de la tramitación parlamentaria del proyecto en el Congreso.

Y no corrió mejor suerte la única enmienda que en el Senado solicitó la supresión de la expresión "actos con fuerza de ley»"61. La Ponencia en su Informe acordó por unanimidad uproponer a la Comisión que no acepte esta enmienda, ya que considera que la referencia a los actos con fuerza de ley es útil para eliminar, en el futuro, ambigüedades interpretativas" ${ }^{62}$. La enmienda ni siquiera fue defendida en el Pleno y no volvió a hablarse más del tema ni en el Senado ni por supuesto en la fase final en que el Congreso hubo de pronunciarse sobre las enmiendas aprobadas por la Cámara alta.

60 DS del CD de 23 de julio de 1979, págs. 1201 y s.

61 La n. ${ }^{\circ}$ 6, del Grupo Mixto, BOCG S, 21 de agosto de 1979.

62 BOCG Senado, 23 de agosto de 1979, pág. 2. 
La conclusión más probable de cuanto acabamos de ver es esta: la existencia de ciertas decisiones, fundamentalmente parlamentarias, que la Constitución no considera deban aprobarse bajo la forma de ley, aconsejaba introducir una formula abierta e imprecisa para que no quedaran fuera del control de constitucionalidad tales decisiones. $Y$ como no son propiamente hablando normas generales y abstractas se optó por llamarlas actos. Si no se quiso poner ejemplos es, probablemente, porque quienes se oponían a la inclusión de la expresión uactos con fuerza de ley" habrían rechazado con facilidad cualquier ejemplo concreto que se pusiera. En efecto ¿cabía imaginar un recurso de inconstitucionalidad contra la inhabilitación regia por las Cortes, por ejemplo? Razones políticas de respeto a las Cámaras (que en muchas intervenciones en aquel debate seguían siendo consideradas soberanas) y de temor a que el Tribunal Constitucional pudiese anular decisiones politicas de la máxima trascendencia donde la regulación jurídica es mínima y la oportunidad y discrecionalidad política máxima, aconsejaban no mencionar ningún caso concreto que pusiera en cuestión la conveniencia de mantener una expresión nueva sin significado doctrinal preciso. Pero mayor era el temor a que en el futuro pudiera quedar exenta de control una decisión de eficacia legislativa e incluso constitucional simplemente porque la forma adoptada no fuera la de "ley" ni "disposición normativa" con fuerza de ley.

En cualquier caso, no puede dudarse que la expresión «actos con fuerza de ley" de la LOTC hace referencia a decisiones singulares (que no sean normas propiamente hablando) con eficacia similar o equivalente a la de una ley. Después aclararemos este último inciso.

$\left.2 .^{\circ}\right)$ Pero lo realmente asombroso del caso es que, si la expresión no figuraba en norma alguna anterior a la la LOTC, tampoco se ha recogido después en texto legal alguno. Ni siquiera, aunque resulte paradójico, en los Estatutos de autonomía al regular el régimen jurídico de impugnación de sus disposiciones. A pesar de que todos ellos se aprobaron después de la LOTC, es significativo que, salvo en el caso de la Comunidad de Murcia ${ }^{63}$, no se mencionen los "actos con fuerza de ley" de los órganos autonómicos como posible objeto de impugnación mediante recurso de inconstitucionalidad ${ }^{64}$. Tampoco aparece la expresión

63 "Las leyes, actos y disposiciones normativas con fuerza de ley de la Comunidad Autónoma, así como el reglamento de la Asamblea Regional solamente se someterán al control del Tribunal Constitucional (art. 53.1).

64 Empezando por el Estatuto vasco, que menciona sólo a las leyes sin hacer referencia siquiera a las "disposiciones normativas con fuerza de ley" (art. 
en el Reglamento del Congreso, ni en el del Senado, ni en la reciente ley del Gobierno ${ }^{65}$, ni en ninguno de los reglamentos parlamentarios de las Asambleas autonómicas ni en ley estatal o autonómica alguna.

3. ${ }^{\circ}$ Además, el Derecho comparado no nos aporta dato alguno que clarifique el significado de la expresión. Sólo en el Derecho italiano podemos encontrarla y para referirse a lo que nosotros llamamos "disposiciones normativas con fuerza de ley" distintas de la misma ley, es decir, fundamentalmente, el decreto-ley y el decreto legislativo ${ }^{66}$. Pero en ninguna parte, que yo sepa, se ha acuñado por la doctrina ni por los textos constitucionales o legislativos la expresión «acto con fuerza de ley" en el sentido que le da nuestra LOTC.

$\left.4 .{ }^{\circ}\right)$ Por su parte, la doctrina española no ha dado mayor importancia a la expresión «actos con fuerza de ley». Ningún trabajo se ha publicado centrado en su estudio y las referencias laterales que podemos encontrar en algunas obras son generalmente tan superficiales que nada aportan a nuestra investigación. Lo único claro en esas referencias es que la doctrina no sabe realmente qué son tales actos ${ }^{67}$.

38), los demás Estatutos que han regulado esta materia (en rigor innecesaria, pues el art. 27 LOTC es mucho más claro y completo al respecto) han citado también únicamente a las leyes como objeto de posible recurso de inconstitucionalidad. Véanse el Estatuto de Cataluña (art. 40), el de La Rioja (art. 29), el de Valencia (art. 29), el de Canarias (art. 41), el de Navarra (art. 37), el de Extremadura (art. 49), el de Baleares (art. 43) y el de la Comunidad de Madrid (art. 43).

65 Su art. 26.3 dice así: "Los actos del Gobierno y de los órganos y autoridades regulados en la presente Ley son impugnables ante la jurisdicción contencioso-administrativa, de conformidad con lo dispuesto en su Ley reguladora", lo que en principio podría interpretarse en el sentido de que ningún acto del Gobierno puede tener fuerza de ley. Pero se añade después que "La actuación del Gobierno es impugnable ante el Tribunal Constitucional en los términos de la Ley Orgánica reguladora del mismo" (art. 26.4), con lo que también podría interpretarse en el sentido de que, aparte del decreto-ley y del decreto legislativo, pudiera existir algún acto del Gobierno sujeto a recurso de inconstitucionalidad, es decir, con fuerza de ley.

${ }_{66}$ Cfr. art. 134 y 136 de la Constitución italiana y arts.23.a y 33 de la Ley de constitución y funcionamiento de la Corte Constitucional.

67 Como muestra véase la afirmación de uno de los autores que más se ha interesado por estos temas: PUNSET, R.: El control jurisdiccional de la actividad de las administraciones parlamentarias y del estatuto de sus miembros "RCG", n. ${ }^{\circ} 5,1985$. Dice respecto de esta clase de actos que udesafían la imaginación de la doctrina y de la jurisprudencia llamadas por el legislador a definir e inventariar los actos en cuestión" (pág. 51). En el más reciente trabajo en que se ha tratado, al menos tangencialmente, esta cuestión se dice de ellos: "categoría ésta ... cuya identificación resulta sumamente problemática en el ámbito estatal y más aún en el ámbito autonómicon. DUQue VILLANUEVA, J. C.: El recurso de amparo contra actos parlamentarios (la vía de amparo del art. 42 LOTC) «RCG» n. ${ }^{\circ} 42$ (1997), pág. 79. 
Dignos de mención son, sin embargo, los trabajos de M. Aragón Reyes y F. Rubio Llorente que alguna pista pueden aportarnos ${ }^{68}$.

Así, mientras Rubio advierte que en nada puede ayudarnos la doctrina de otros paises en torno al concepto de "fuerza de ley", demuestra la imposibilidad de seguir entendiéndola en el sentido que inicialmente tuvo: lo que se ha venido en llamar la "fuerza activa" de ley o poder de derogar una ley anterior y la ufuerza pasiva" o imposibilidad de ser derogado sino por una ley posterior. Nada de esto sirve para construir el concepto que en nuestro Ordenamiento puede tener la expresión "acto con fuerza de ley". Por su parte, Aragón reconoce la falta de una doctrina elaborada en torno a lo que puedan ser actos con fuerza de ley. Ciertamente, afirma, no pueden ser "normas", sino «actos", esto es, decisiones concretas ${ }^{69}$ : "serían actos cuya fuerza de ley les vendría dada por la intervención parlamentaria en su emanación" y cita como ejemplos muchos de los que aquí hemos considerado como actos constitucionales: la convalidación o no por el Congreso de los decretos-leyes, la autorización o no para la ratificación de tratados del art. 94.1 CE, la convocatoria de referendum (que es sin embargo un acto regio, cuyo valor de ley le vendría, según Aragón, de la autorización previa del Congreso, art. 92.2 CE), la apreciación de la necesidad de dictar una ley armonizadora (art. 150.3 CE), la aprobación por el Senado de las medidas de intervención del art. 155.1 CE, el decreto de declaración del estado de excepción (también es un acto regio), o la declaración por el Congreso del estado de sitio, y, más dudosamente, la autorización del Congreso al Gobierno para que prorrogue el estado de alarma. En todos estos casos la "fuerza de ley no parece ofrecer dudas, y no sólo por la preceptiva intervención parlamentaria ... sino también por los efectos jurídicos que tales decisiones pueden producir". En todo caso advierte que los ejemplos anteriores "no son seguramente los únicos que pueden encontrarse en nuestro ordenamiento" y que "habría que indagar también qué actos con fuerza de ley de las Comu-

68 Del primero, el Comentario al art. 161 de la Constitución, en «Comentarios a las leyes políticas. Constitución española de 1978», dirigidos por O. ALZAGA, Tomo XI, Madrid 1988 y sobre todo la voz acto con fuerza de ley de la «Enciclopedia Jurídica Básican de Civitas, Tomo I, Madrid 1995, págs. 181 a 183. Del segundo, Rango de ley, fuerza de ley, valor de ley, publicado inicialmente en la "Revista de la Administración Públican núms. 100 - 102 (1983), págs. 417 a 435. De ambos conjuntamente La jurisdicción constitucional, en la obra "La Constitución española de 1978. Estudio Sistemáticon dirigida por Predierl, A. y Garcla de EnTERria, E., Madrid 1980.

69 Acto con fuerza de ley, cit, pág. 181. 
nidades puede haber" ${ }^{70}$, aunque él no cita ninguno. En todo caso, da por sentado que sólo pueden ser actos con fuerza de ley los que tienen un origen o aprobación parlamentarios.

Aparte estas referencias, sólo algunas indirectas para incluir o no ciertos actos dudosos dentro de la categoría que analizamos, he encontrado en la doctrina. Así, Cruz Villalon defiende que el decreto de declaración del estado de excepción, el de prórroga del estado de alarma y la propia declaración del estado de sitio son actos con fuerza de ley, pero no lo sería el real decreto de declaración del estado de alarma por no existir intervención parlamentaria ${ }^{71}$. Astarloa Huarte-Mendicoa menciona, sin más explicaciones, como actos con fuerza de ley de las Cámaras la convalidación de los decretos-leyes, la autorización de tratados y el control, en su caso, de los decretos legislativos ${ }^{72}$. Rodríguez Oliver rechaza tajantemente que la declaración de los estados de anomalía pueda ser en ningún caso un acto con fuerza de ley: el decreto de declaración del estado de alarma es, a su juicio, un acto administrativo más, el de declaración del estado de excepción es un "acto no administrativo" del Gobierno pero exento de control jurisdiccional (pese a que considera extintos los actos políticos del Gobierno) y la declaración del estado de sitio por el Congreso es simplemente un acto sin fuerza de ley de la Cámara y como tal sujeto a recurso de amparo, que seria sin embargo imposible en la práctica en su opinión, por no poder suponer nunca una violación directa de derechos fundamentales. En definitiva, no son actos con fuerza de ley ${ }^{73}$.

$\left.5 .{ }^{\circ}\right)$ Por si el panorama doctrinal fuera poco confuso, el Tribunal Constitucional ha venido a introducir mayor incertidumbre si cabe sobre tal categoría de actos jurídico-públicos. La única vez en que el Alto Tribunal ha considerado encontrarse ante un acto con fuerza de ley ha sido en la Sentencia 139/1988, de 8 de julio. En tal ocasión se afirmó que el Estatuto del Personal de las Cortes Generales es un acto

70 Loc. cit., págs. 182 y s.

71 El nuevo derecho de excepción, "REDC», vol I, n. 2 (1981) pág. 115 y s. y también en Estados excepcionales y suspensión de garantías, Madrid 1984, pág. 139 y s. A este respecto, yo mismo he defendido el carácter de actos con fuerza de ley de los reales decretos de declaración, prórroga y levantamiento del estado de alarma. El estado de alarma y su ambigua naturaleza "CCFFC", n. 8, (1994), págs. 104 ys.

pág. 223.73 Los ámbitos exentos del control del Tribunal Constitucional español, en la obra «EI Tribunal Constitucional» Volumen III, Madrid 1981, págs. 2.315 a 2.319. 
con fuerza de ley (FFJJ $2 .^{\circ}$ y $3 .^{\circ}$ ). El problema estaba en que ni la Constitución (arts 72.1 y 161.1.a) ni la LOTC (art. 27.2) mencionan dicha norma entre las que pueden ser objeto de un recurso de inconstitucionalidad. Considerarla como un simple reglamento administrativo repugnaba a la idea de norma de aprobación parlamentaria y a su carácter de "norma primaria" (o "acto normativo primario" como dice el propio Tribunal para justificar el salto lógico que iba a realizar a continuación ${ }^{74}$ ), es decir, directamente incardinado en la Constitución. Pero fue el remedio peor que la enfermedad, porque, para poder considerár a dicho Estatuto como norma con rango de ley sujeta a control de constitucionalidad y no como reglamento sujeto a control jurisdiccional contencioso-administrativa, se entendió que ubien puede subsumirse sin dificultad alguna el referido Estatuto en la categoría de acto del Estado con fuerza de ley". Pero una norma no es un acto ni la mixtura de ambos conceptos en la idea de "acto normativo" puede disimular el error en que, con tal razonamiento, incurrió el Tribunal Constitucional. Más correcta era, a mi juicio, la opinión de la Sala $3 .^{a}$ del Tribunal Supremo en la Sentencia de 20 de enero de 1987, objeto de la impugnación ante el Constitucional que originó la STC que comentamos, que admitía claramente sobre dicho Estatuto que «se trata de una auténtica ley, en la medida en que tales normas reglamentarias proceden de los órganos legislativos y enlazan directamente con la norma constitucional». La frase fue recogida en la STC en términos elogiosos, pero el Tribunal sintió la necesidad de modificar la calificación de la norma cuestionada: no sería una "auténtica ley", sino un acto con fuerza de ley. El resultado práctico era el mismo, pero mientras el Tribunal Supremo respetaba el significado más común y razonable de la expresión "acto", el Constitucional, aferrándose al concepto estrictamente formal de ley, se vio en la necesidad de forzar el sentido de la palabra "acto" por temor a que se pudiera considerar "ley" una norma jurídica que carece de dicho nombre ${ }^{75}$. La explicación más probable a esta forma de actuar está en lo que Schmitt denominara "formalismo desesperado" de considerar como ley, desde luego

74 STC cit, FJ 2:.

75 Parece pues que el Tribunal Constitucional utilizó la expresión acto en el sentido amplio que tiene en el Derecho italiano, donde, por ejemplo, los decretoleyes son "actos normativos" pero esta significación no es frecuente entre nosotros. Basta con ojear cualquier manual de Derecho administrativo para comprobarlo. Además de que en los textos legales españoles (por ejemplo, en la nueva LJCA) queda clara la significación del término acto y la distinción entre "acto" singular $y$ «disposición» general. 
en Alemania ${ }^{76}$, pero también aquí ${ }^{77}$, a todo lo que un Parlamento aprueba con tal nombre ${ }^{78}$.

En conclusión: hemos de reconocer que a cerca de veinte años de la introducción de la expresión "actos con fuerza de ley" en la LOTC seguimos sin saber a ciencia cierta, no ya cuáles son, sino ni siquiera qué son tales actos. Parece, sin embargo, que se trata de un simple artificio procesal creado para evitar que ciertas decisiones singulares de eficacia constitucional o legislativa quedaran exentas de todo control jurisdiccional.

\section{Los actos constitucionales son los actos con fuerza de ley}

Tal es la tesis central de toda esta investigación. He tratado de demostrar que existe una categoría específica de actos jurídico-públicos distintos de los actos administrativos y de las normas de cualquier rango a los que aquí llamamos actos constitucionales. Hemos visto después que tales actos se controlarán jurisdiccionalmente según tengan o no la categoría de uactos con fuerza de ley" introducida extrañamente en la LOTC. Por último hemos comprobado que existe hoy por hoy una enorme incertidumbre en torno a la naturaleza (no digamos ya al catálogo) de tales actos con fuerza de ley. Me propongo demostrar ahora que los actos constitucionales son precisamente los actos con fuerza de ley. Es decir, no que algunos actos constitucionales tengan fuerza de ley, ni que algunos actos con fuerza de ley sean actos constitucionales, sino que se da una perfecta coincidencia entre ambos con-

76 Cfr. Bulow, E.: La legislación, en Benda, Maihofer, Vogel, Hesse, Heyde «Manual de Derecho constitucional". Traducción española, Madrid 1996, pág. 729 y StaRCK, C.: El concepto de ley en la Constitución alemana. Madrid 1979, especia!mente el Cap. $10^{\circ}$.

77 Si exceptuamos la decidida defensa de un concepto material de ley por N. Pérez Serrano Tratado de Derecho político, 2." Edición, Madrid 1984, págs. 399 y s. y por L. SÁNCHEZ AGESTA El sistema político de la Constitución española de 1978, Madrid 1980, pág. 292, parece existir una rara coincidencia en aceptar sin discusión que es ley todo lo que aprueban las Cortes o las Asambleas legislativas de las Comunidades autónomas bajo ese nombre. Opinión ésta plenamente asumida con todas sus consecuencias procesales por el propio Tribunal Constitucional, como se demuestra, por ejemplo en el ATC 46/1993.

78 De acuerdo con la Constitución, el Estatuto de las Cortes Generales se regula de común acuerdo entre ambas Cámaras (art. 72.1). En la práctica se ha producido una extraña delegación legislativa en las Mesas del Congreso y del Senado que reunidas conjuntamente aprueban y modifican dicho Estatuto. 
ceptos: todo acto constitucional es un acto con fuerza de ley y no existen más actos con fuerza de ley que los actos constitucionales.

Para ello habrá que empezar por aclarar qué quiere decir aquí $y$ ahora, es decir, en el actual Ordenamiento español "fuerza de ley". Una vez aclarada la idea veremos si los que denomino actos constitucionales encajan y por qué en tal idea.

A. Un estudio riguroso sobre el significado -tanto original como actual- de la expresión "fuerza de ley" y de otras próximas a ella: "rango de ley" y "valor de ley" fundamentalmente, está aun por hacer. Si no me equivoco, quien más ha tratado de aproximarse a una clarificación de esta idea es el profesor Rubio Llorente. De sus estudios y de las reflexiones de otros autores creo pueden extraerse las siguientes conclusiones:

$1^{\circ} .^{\circ}$ La expresión fuerza de ley surge en la Revolución francesa (force de (oi) y significaba que ciertas decisiones de la Asamblea Nacional que no se llamaban leyes (seguramente porque no precisaban de sanción regia) tenían capacidad de derogar disposiciones legales y no podían ser derogadas, a su vez, más que por leyes ${ }^{79}$. Así, la Constitución francesa de 1791 declaraba que "los decretos del Cuerpo legislativo tienen fuerza de ley y llevan el título y nombre de leyes" (Tít. III, Cap. III, Sec. $3{ }^{a}$, art. $6 .^{\circ}$ ) y a continuación se añadía en el artículo siguiente que ciertos actos del Cuerpo legislativo sin el nombre de leyes por no haber sido sancionadas por el Rey, "serán sin embargo ejecutados como leyes", es decir, estarán dotados de fuerza de ley ${ }^{80}$. Esa fuerza consistía en la absoluta irresistibilidad de la ley, puesto que «en Francia ninguna autoridad es superior a la de la ley" (Tit. III, Cap. II, Sec. $1 .^{a}$, art. $3 .^{\circ}$ de la Constitución de 1791). Fuerza de ley significaba pues, en su sentido originario, decisión emanada del órgano soberano, esto es, de la Asamblea Nacional. Pero como algunas decisiones soberanas eran tomadas sin forma de ley sino con la de "decreto", se aclaraba que éstos tenían el mismo valor, la misma fuerza que una verdadera ley.

2..$^{\circ}$ Esta expresión pasó a España desde el primer momento, pues ya el art. 60 del Estatuto de Bayona de 1808 establecía que «los

79 "La fórmula 'fuerza de ley' aludía a la condición soberana de la manifestación de la voluntad general: esto es, el acto de voluntad más alto y enérgico que puede emanar del Estado, al que todos están incondicionalmente sometidos y que el monarca, desde luego, no puede modificar ni anular por si solo" Santamaria PasTOR, J. A.: Fundamentos de Derecho administrativo I, Madrid 1988, pág. 543.

80 Отто, І. De: Derecho constitucional. Sistema de fuentes. Barcelona, 1987, pág. 105. 
decretos del Rey sobre objetos correspondientes a la decisión de las Cortes, tendrán fuerza de ley hasta las primeras que se celebren, siempre que sean ventilados en el Consejo de Estadon. Y las Cortes de Cádiz dictaron numerosos "decretos" de evidente eficacia legislativa y hasta constitucional. Y por ello durante buena parte del siglo XIX el estado de guerra o el de sitio era declarado por decreto, no por ley ${ }^{81}$. Decretos que, evidentemente tenían fuerza de ley, aunque fueran dictados a veces sin autorización de las Cortes, es decir, por el Rey y su Gobierno. Ya en este siglo, con la Dictadura de Primo de Rivera se legalizan los reales decretos "con fuerza de ley", que no sólo podían contener normas sino actos jurídicos singulares ${ }^{82}$. Posteriormente, la expresión fuerza de ley se reservó para los decretos leyes y decretos legislativos, es decir, normas dictadas excepcionalmente por el Ejecutivo pero necesitadas de autorización o convalidación parlamentaria ${ }^{83}$.

3. ${ }^{\circ}$ Sin embargo, fue la Escuela alemana del Derecho público la que elaboró una doctrina sobre el significado técnico de la expresión fuerza de ley (Gesetzeskraft) un siglo después de su aparición en Francia, y lo hizo en el marco de la discusión en torno al sentido material y formal de ley ${ }^{84}$. Para lo que ahora interesa, la fuerza formal de ley sería doble: la disposición que tenga fuerza de ley puede derogar leyes ("fuerza activa») y sólo por ley pueden ser derogada ("fuerza pasiva»).

$4 .^{\circ}$ ) Ya en el primer tercio del siglo $x x y$ sobre todo en Francia se comenzó a fijar el núcleo del concepto en la eficacia vinculante de la ley respecto de las personas de sus aplicadores empleando la noción de "ejecutoriedad" ${ }^{85}$. Así, las leyes son inmunes al control por los jueces. $Y$ de este rasgo de supremacía sobre los jueces surgiría la expresión "valor de ley" en Italia en los años cincuenta ${ }^{86}$ como algo próximo

81 Véase como ejemplo el Real decreto de 1 de marzo de 1868 (Gaceta de Madrid de 2 de marzo de 1868) declarando el estado de guerra en media España.

82 Real decreto de 15 de septiembre de 1923, art. $1 .^{\circ}$.

83 Véase arts. 61 y 80 de la Constitución española de 1931 y art. 51 de la Ley Orgánica del Estado, completado por el art. $10.4 .^{\circ}$ de la Ley de Régimen Jurídico de la Administración del Estado, que continuó vigente hasta hace muy poco tiempo.

84 Especialmente G. JelLINEK, Gesetz und Verordnung, Freiburg 1887, págs. 75 y ss. y P. LABAND Das Staatsrecht des Deutschen Reiches II, 5. Edición, Tübingen 1911 , págs. 68 y ss.

85 Santamaría Pastor, J. A.: Fundamentos de Derecho administrativo I. Madrid 1988, pág. 544.

${ }^{86}$ A partir de un célebre artículo de A. M. SANDULLI Legge, Forza de legge. Valore di legge. en la "Riv. Trim. Dir. Pubbl." (1957), págs. 269 y ss. que tuvo una gran resonancia en su momento, si bien después ha sido fuertemente criticado considerando inútil tal distinción. En este sentido, véase, por ejemplo, las afirmaciones 
pero distinto de la fuerza de ley para explicar la existencia de normas en las que no coincidían la fuerza (activa o pasiva) con la inmunidad frente al poder judicial ( $y$ consiguiente monopolio de control por la Corte Constitucional). El clásico principio de sumisión del poder judicial al imperio de la ley, recogido hoy expresamente en la Constitución española de 1978 (art. 117.1), significaba a estos efectos que cualquier disposición con valor de ley estaba excluida de control por parte de los tribunales -hoy diriamos "ordinarios»- que "no pueden moderar ni su fuerza ni su rigor», en palabras del propio Montesquieu.

$\left.5 .^{\circ}\right)$ Con la aparición del control de constitucionalidad sobre las leyes pierden éstas su fuerza irresistible, pues quedan en segundo lugar en el sistema de fuentes, pero siguen teniendo una fuerza superior a la de cualquier otra norma jurídica fuera de la Constitución. De ahí que "valor de ley" ha venido a significar después el que corresponde a aquellas disposiciones exentas de control judicial pero, por contra, sujetas a impugnación ante el Tribunal Constitucional. Pero esta cualidad procesal deriva a su vez de que sobre aquellas disposiciones que tienen valor de ley no cabe control de legalidad alguno, sino sólo de constitucionalidad porque se encuentran directamente incardinadas en la Constitución, son "normas primarias".

6. ${ }^{\circ}$ De ahí surgió otra expresión análoga, la de "rango de ley", que puede utilizarse sin más como sinónimo de valor de ley o bien añadir a la idea un matiz nuevo: el "rango de ley" sería la cualidad que tienen hoy las leyes de encontrarse jerárquicamente por debajo de la Constitución y por encima de los reglamentos. Se ha dicho, por eso que el rango precedería a la fuerza y al valor de ley, que serían consecuencias del primero ${ }^{87}$, lo cual es cierto desde un punto de vista lógico, pero no histórico.

En definitiva: en su sentido originario, por "fuerza de ley" hemos de entender la cualidad de una norma jurídica de poder derogar las leyes anteriores y de no poder ser derogada más que por otra ley o norma con dicha fuerza, unido a la idea de supremacía absoluta de la ley sobre las otras fuentes del Derecho. El "valor de ley" sería el privilegio que corresponde a las leyes y otras normas asimiladas de ser inmunes al control judicial y en consecuencia, hoy en día, de ser enjuiciables únicamente por el Tribunal Constitucional. Por último, el «rango

de A. Pizzorusso Lecciones de Derecho Constitucional II, Edición española, Madrid 1984, pág. 257.

87 Cfr. Balaguer Callejón, F:: Fuentes del Derecho Il, Madrid 1992, pág. 56. 
de ley" sería la cualidad jerárquica propia de aquellas normas jurídicas infraconstitucionales y suprarreglamentarias.

B. Sin embargo, al intentar trasladar estas expresiones al Derecho positivo español actual nos encontramos con que el uso que de las mismas hace la Constitución o la LOTC, la propia jurisprudencia constitucional, y por supuesto la doctrina, tiene poco que ver con el significado que en teoría debe corresponderles ${ }^{88}$.

En primer lugar, porque se ha diversificado hasta límites increíbles la propia fuerza de ley. En rigor, ya no existe una sola fuerza de ley, sino una de la ley orgánica, otra de la ordinaria, otra del decreto-ley, otra fuerza del decreto-legislativo, otra de la ley autonómica, otra del reglamento parlamentario, etc. De cada uno de estos tipos de normas ya no puede predicarse que tiene la capacidad incondicional de modificar las leyes (sino sólo algunos tipos de leyes, o leyes de su mismo tipo o leyes que no versen sobre determinadas materias) ni por tanto que sólo puedan ser modificadas por leyes (sino sólo por algunos tipos de leyes o leyes de su mismo tipo o por leyes que versen sobre determinadas materias).

El concepto teórico de valor de ley tampoco resulta hoy aplicable: ni las leyes están inmunes del control positivo de constitucionalidad que ejercen los jueces, o incluso el negativo si son preconstitucionales, ni son inmunes los excesos de delegación contenidos en los decretos legislativos.

$Y$ en cuanto al rango, ya no es tan claro su sentido, pues la existencia de leyes que forman parte del parámetro de enjuiciamiento de la constitucionalidad de otras y más aún de leyes autonómicas jerárquicamente sometidas al estatuto de autonomía que es una ley estatal, impiden considerar la existencia de un único y delimitado rango jerárquico intermedio entre la Constitución y el reglamento.

Por eso, cuando analizamos los diversos preceptos que en la Constitución y en la LOTC mencionan estas expresiones se comprueba lo siguiente: fuerza, rango y valor de ley son utilizados como expresiones prácticamente sinónimas. Prácticamente quiere decir que según el contexto concreto es posible o no encontrar algún matiz diferenciador que puede o no tener relación con el significado doctrinal clásico de las expresiones. Un estudio exhaustivo, que no es necesario exponer

88 Asi, Rubio LloRente, F: Rango de ley, fuerza de ley, valor de ley, cit. pág. 422 considera que ni la Constitución ni la LOTC permiten atribuir ya el contenido clásico a la expresión fuerza de ley. 
ahora, de los diversos artículos de la Constitución y de la LOTC que mencionan tales conceptos, así como de su uso en la jurisprudencia constitucional nos llevarian a esa conclusión ${ }^{89}$.

Por tanto no tiene sentido hoy buscar diferencias entre los tres conceptos. O reconocemos que se utilizan en la Constitución, en la LOTC y en la jurisprudencia constitucional prácticamente como sinónimos o habrá que reconocer que su uso es sencillamente caótico, incoherente, anárquico. Así pues, decir de un acto que tiene fuerza de ley es afirmar que no está sujeto a control por el Poder judicial, sino sólo por el Tribunal Constitucional. Pero ya no significa en absoluto que tenga virtualidad para derogar leyes, cosa que en rigor ya no pueden hacer muchas leyes respecto de otras específicas.

Según esto, acto con fuerza de ley quiere decir en la LOTC, único lugar donde tal expresión se utiliza, acto singular -y no norma-cuyo control se reserva al Tribunal Constitucional en los procesos de inconstitucionalidad siendo inmune de cualquier control por los tribunales ordinarios.

La pregunta es entonces por qué tales actos reciben ese privilegio. La respuesta estriba en el carácter directamente incardinado en la Constitución que caracteriza a los actos constitucionales, incluso cuando una ley complementa los preceptos de la Constitución que regulan la emisión de tales actos.

En otras palabras, un acto constitucional es un acto con fuerza de ley porque aquí la expresión "fuerza de ley" no significa, como en su origen, que pueda derogar una ley, sino que tiene el mismo rango $y$ valor que una ley. Mismo rango, mismo valor y misma fuerza que una ley quiere decir aquí y ahora que en dichos actos se aplica directamente un precepto constitucional o se le da complemento necesario para que pueda aplicarse y por tanto el único control jurisdiccional que cabe sobre ellos es el control de constitucionalidad. Al no existir control de legalidad propiamente dicho, pues los actos con fuerza de ley no se incardinan en ley alguna sino directamente en la Constitu-

89 Es posible encontrar sentencias del Tribunal Constitucional que se contradicen flagrantemente en el uso de las expresiones. Así, por ejemplo, el ATC $244 / 86$ y la STC $118 / 1988$, FJ 3. ${ }^{\circ}$ las utilizan como sinónimos. y en cambio en la STC $119 / 1990$, afirma del reglamento parlamentario que es unna norma con valor de Ley, aunque desprovista de la fuerza propia de la Ley" (FJ 2. \%. La razón es evidente: los propios magistrados del Tribunal Constitucional no saben a ciencia cierta si rango, valor y fuerza de ley son lo mismo o si es posible hoy diferenciar los tres conceptos. 
ción, sólo el Tribunal Constitucional puede fiscalizarlos, incluso aunque para ello tenga que aplicar como "bloque de constitucionalidad" de dicho acto, además de la propia Constitución formal, algunas leyes concretas y específicas.

Si las leyes y normas con rango, valor y fuerza de ley son «normas primarias" directamente subordinadas a la Constitución aunque deban también respetar entero el bloque de constitucionalidad constituido por algunas leyes específicas, los actos con fuerza de ley son "actos primarios" subordinados también solamente al bloque de constitucionalidad.

Pero es que, además, el sentido originario de la fuerza de ley no deja de estar presente en los actos constitucionales. Obsérvese que en materia de emisión de actos constitucionales no existen casi nunca reglamentos, sino todo lo más leyes que complementen la escueta regulación constitucional de la emisión de tales actos y que, si en algún caso llegaran a darse, el incumplimento de las normas contenidas en dichos reglamentos no invalidarian el acto constitucional que se encuentra, sin ser propiamente una norma, en la misma posición jerárquica que la ley. Al contrario, por tanto de lo que sucedería con un acto administrativo respecto de un reglamento, que sí le vincula incluso si la disposición que aprueba el acto es formalmente de rango superior a la que aprueba la norma reglamentaria en virtud del principio de «inderogabilidad singular de los reglamentos».

Así, por ejemplo, si las Cortes hubieran de nombrar tutor del Rey menor de edad (art. 60.1 CE) y en el acto de designación se le diese el tratamiento de Alteza, ¿sería nulo dicho acto por contravenir el Real decreto 1368/1987, de 6 de noviembre, por el que se establece el régimen de títulos, tratamientos y honores de la familia real y de los regentes? Dicho reglamento prohibe en su art. 3.3.c. que nadie pueda recibir tal tratamiento fuera de los casos que allí expresamente se mencionan, entre los que no está el Tutor del Rey. Pero igualmente, si el acto constitucional mencionado se hubiera dictado antes que el reglamento ¿podría alguien creer que la aprobación de éste supone derogación de aquel? $\mathrm{Si}$, pues, el acto constitucional puede contravenir un reglamento y en cambio nunca un reglamento podrá modificar un acto constitucional, es prueba evidente de que dicho acto tiene fuerza de ley en el sentido más clásico de la expresión. A una conclusión análoga nos llevaría el análisis de los actos regios si no fuera porque la actual confusión entre actos del Rey y actos del Gobierno, acentuada por la nueva LJCA, los asemeja, de forma aberrante, a actos administrativos.

C. Independientemente de lo anterior, existe otra vía para llegar al significado técnico de la expresión actos con fuerza de ley utilizada 
por la LOTC. Se trata de indagar el problema político que subyace a la formación de esta idea y que hunde sus raices directamente en la discusión en torno a la dualidad de conceptos, formal y material, de ley en la dogmática alemana del Derecho público. Carl Schmitt, en su crítica feroz a lo que denomina "formalismo desesperado" de considerar ley todo lo que aprueba una Asamblea parlamentaria, acertó a indicar el origen de tal concepción: «Si es característico de la organización de la Monarquía constitucional el que sólo pueda hacerse una ley con la cooperación de la Representación popular, que ha luchado por ensanchar el volumen de su cooperación, extendiéndola en lo posible a todos los actos políticos importantes -concesión de tributos, aprobación del presupuesto, declaración del estado de sitio, declaración de guerra, nombramientos, otorgamiento de la gracia, concesiones de empresas importantes, anexiones de municipios, cambios de territorio, etc- no es más que un simple ardid de técnica verbal, y no otra cosa, el fijar en ley constitucional que tales actos políticos se realizan 'en forma de ley' 0 cuando se establece consuetudinariamente que para tales actos haya de elegirse el procedimiento de la legislación ${ }^{90}$. Dejando a un lado el tema que a él le preocupa, no cabe duda que la mayor parte de los actos políticos que cita corresponden con verdaderos actos constitucionales, incluidos los nombramientos. $Y$ aunque él escribe en el contexto de la Constitución de Weimar y dentro de la tradición dogmática derivada de la monarquía constitucional, sus afirmaciones valen también para el actual Derecho público español: las Cortes, además de hacer leyes $-y$ algunos de los actos constitucionales citados en este pasaje por Schmitt se aprueban aquí y ahora con forma de ley- toman muchas otras decisiones políticas que no se formalizan como leyes $y$ que sin embargo, si se atribuyen constitucionalmente a las Cortes es por su importancia política vital o si se prefiere porque afectan vitalmente al proceso político estatal. Tal es el caso de la declaración del estado de sitio o del nombramiento de vocales del Consejo General del Poder Judicial o la mayor parte de los magistrados del Tribunal Constitucional y por supuesto, de los actos relativos a la determinación de quién ha de ser Presidente del Gobierno (investidura, censura) y no digamos nada de los que afectan a la Jefatura del Estado (inhabilitación regia, nombramiento de regencia o de tutor del Rey, etc). Todos ellos son verdaderos y auténticos actos constitucionales en el sentido que aqui le hemos dado a la expresión. Ahora bien, tales actos constitucionales ya no son hoy monopolio del Parlamento. Del mismo modo que

90 Teoría de la Constitución, versión española, Madrid 1982, 1. ${ }^{a}$ Reimpresión de 1992, pág. 153. 
los recelos contra la institución parlamentaria (provocados por los abusos cometidos contra la Constitución en el siglo pasado y primeras décadas del actual, y también por la crisis del parlamentarismo de entreguerras), trajo consigo la creación de Tribunales de garantías constitucionales que limitan severamente el poder antes soberano de las asambleas parlamentarias, pudiendo anular incluso las leyes por ellas aprobadas cuando no respeten la Constitución, también por los mismos recelos se ha diversificado la toma de esas otras decisiones políticas vitales entre órganos y sujetos distintos. Así, en el nombramiento de magistrados del Tribunal Constitucional no sólo intervienen las Cortes, sino el Gobierno y el Consejo General del Poder Judicial; en la declaración de los estados de anomalía no sólo interviene el Congreso, sino, el Gobierno (recuérdese que sólo a él le está reservada la propuesta para la declaración del estado de sitio). Y la reforma de la Constitución, al menos en los supuestos principales o a falta de consenso parlamentario casi absoluto, debe ser ratificada por el pueblo. Ahora bien, tales actos políticos vitales no dejan de serlo por el hecho de que su determinación ya no corresponda al Parlamento. Es decir, aunque la decisión sea de otro órgano constitucional, sin embargo siguen siendo actos "con fuerza de ley".

O dicho de otra forma: toda decisión con eficacia jurídica externa directa adoptada por una Cámara parlamentaria tiene en principio fuerza de ley y por lo mismo rango y valor de ley: sólo el Tribunal Constitucional $-y$ precisamente en Pleno- puede enjuiciar su valide $z^{91}$. Pero las decisiones parlamentarias no siempre adoptan la forma de leyes (la adoptan la mayor parte de las veces, sea porque contienen verdaderas normas, sea porque se trata de actos singulares que la Constitución quiso se aprobaran con forma de leyl, sino que en ocasiones carecen de tal forma ( $y$ en estos casos nunca contienen normas sino actos constitucionales) y no por eso tales decisiones parlamentarias quedan exentas de sumisión a la Constitución y por ello exentas de control jurisdiccional alguno. Pero como son parlamentarias no parecería coherente que fueran los tribunales ordinarios, sometidos al imperio de ley (vale decir de la voluntad del Parlamento debidamente formalizada)

91 Nótese que por la vía del recurso de amparo pueden impugnarse los "actos sin valor de ley emanados de las Cortes o de cualquiera de sus órganos" (art. 42 LOTC) y que en la práctica se da la paradoja de que los únicos actos de este tipo que proceden de las Cámaras mismas (no de sus órganos directivos) enjuiciados por esta via son las denegaciones de suplicatorios, es decir, precisamente aquelios actos que están exentos de control por el poder judicial, o lo que es lo mismo, los actos con "valor de ley» en el sentido original de la expresión. 
quienes pudieran enjuiciar tales decisiones. $Y$ si son inmunes al control judicial es que tienen el status privilegiado del "valor" o "rango" de las leyes $y$ en consecuencia se les puede denominar actos con fuerza de ley. El que hoy en día los actos constitucionales no sean siempre decididos por las Cámaras, sino en ocasiones por otro órgano constitucional distinto ( $y$ entonces precisan siempre formalización como acto regio mediante un real decreto) no modifica la naturaleza y por tanto el valor, rango y fuerza de dicho acto constitucional.

Ciertamente, Schmitt parte de la construcción dogmática alemana basada, hasta la República de Weimar, en el principio monárquico: el titular originario de la soberanía era el Rey y las Asambleas eran simples órganos de limitación de este poder originario. En la tradición de la Revolución francesa y por tanto también aquí, el principio democrático, que considera a la representación popular no como un simple instrumento de limitación del poder soberano del Rey sino como el titular único de la soberanía, las consecuencias no han sido, sin embargo, muy distintas: los actos de soberania, como lo eran hasta tiempos recientes las propias leyes, no son privativos de las Cortes, pues el Gobierno puede legítimamente dictar normas capaces de derogar las leyes y por supuestos actos constitucionales, como la declaración del estado de excepción (que también precisa autorización parlamentaria, pero que no puede realizar por si mismo el Congreso). $Y$ del mismo modo que la sanción regia de las leyes subsiste en nuestra Constitución como un residuo de lo que en otro tiempo fue la participación regia necesaria en la aprobación de las leyes, así mismo todos los actos constitucionales que por deseo de la Constitución proceden de órganos distintos del propio Parlamento, necesitan ampararse en la autoridad regia, es decir, sólo pueden aprobarse mediante real decreto. Por tanto, junto a los decretos del Gobierno -o de su Presidente- que podrán siempre ser controlados por los tribunales ordinarios tras la nueva LJCA (vale decir, que nunca tienen valor de ley) existen los decretos del Rey, los que aprueban actos constitucionales inmunes a control judicial porque tienen valor, rango y por tanto fuerza de ley en el sentido anteriormente indicado. Sólo el Pleno del Tribunal Constitucional puede invalidar uno de tales actos formalizados amparándose en la autoridad regia.

D. Veíamos en su momento que los actos constitucionales pueden agruparse en tres categorías: los que deciden sobre las personas de los gobernantes superiores del Estado, los que activan preceptos constitucionales que excepcionan temporalmente la vigencia de otros y los que dictan las Cámaras para dar su autorización -o convalidación- 
a una norma con rango de ley dictada o negociada por el Gobierno. Hemos visto también que la doctrina, aunque dividida al respecto, puede aceptar el carácter de acto con fuerza de ley de los mencionados en las categorías segunda y tercera. Pero nadie, que yo sepa, ha considerado hasta ahora que los actos constitucionales de designación de gobernantes máximos del Estado puedan ser considerados actos con fuerza de ley. Más aún, en la única ocasión en que se ha impugnado ante el Tribunal Constitucional un acto de este tipo (el nombramiento o más exactamente la propuesta al Rey de nombramiento de Presidente de la Comunidad foral de Navarra), el Alto Tribunal admitió un recurso de amparo y una impugnación de las del art. 161.2 CE contra dicho acto, evidentemente por entender que carecía de valor de ley ${ }^{92}$.

Pues bien ¿por qué motivo deben considerarse actos con fuerza de ley aquellos que determinan las personas que han de ocupar los cargos supremos en el Estado? La razón es la siguiente. Ninguna función atribuida por la Constitución puede ejercerse sin que antes se produzca el acto formal de designación de la persona o personas concretas que han de ejercerlas. Las funciones, competencias $y$ atribuciones que asigna la Constitución necesitan siempre y necesariamente ese complemento que es el acto de designación de los gobernantes, sin el cual no se actuaria nunca la competencia o función atribuida. Precisamente por eso, la determinación de las personas concretas que ocuparán los cargos máximos de gobierno es uno de los actos políticos más importantes de la vida política estatal, como lo demuestra que en todas partes sea la propia Constitución formal la que regule el procedimiento de designación de tales gobernantes. Ahora bien, la determinación de quién o quienes ocuparán dichos cargos supremos está sujeta siempre a normas, y precisamente normas constitucionales, al menos en lo fundamental del procedimiento de designación. El acto pues de designación de un gobernante superior del Estado es un acto constitucional

92 Dos observaciones, sin embargo, merecen hacerse a aquella sentencia. La primera es que no se trataba estrictamente hablando de una decisión parlamentaria, sino de una propuesta del Presidente de la Cámara tomada ante la falta de acuerdo parlamentario para investir a un candidato a la Presidencia de la Comunidad con base en una interpretación de las normas aplicables (la LORAFNA y el Reglamento parlamentario principalmente) rechazada e impugnada por otro candidato que se consideraba con más derecho a Presidir el Gobierno de Navarra, y por el Presidente del Gobierno que era, además quien tenia que refrendar el Real decreto de nombramiento de Presidente autonómico. La segunda observación es que los tribunales contencioso-administrativos inadmitieron los recursos previos ante ellos planteados y tal inhibición fue considerada correcta por el Tribunal Constitucional, que consideró que no era un acto administrativo sino «materia constitucional» (sic). 
estricto, esto es, la aplicación de una norma general y abstracta que se encuentra en la Constitución formal a un momento concreto $y$ determinado de la vida del Estado.

Pero es que, además, los mismos cargos de gobierno cuya forma de designación regula la Constitución, coinciden normalmente con aquellos que tienen atribuida la potestad legislativa, la de dictar normas con rango de ley o de enervar directa o indirectamente su eficacia. Incluso en dos casos menos claros, como son el Defensor del Pueblo y el Consejo General del Poder Judicial, es preciso recordar que el primero puede presentar recursos de inconstitucionalidad contra leyes (de hecho, cuando los grandes partidos pactan no recurrir por razones políticas puede ser el único órgano legitimado para recurrir que esté en condiciones reales de hacerlo). Respecto al segundo, puede presentar conflictos constitucionales de atribuciones incluso contra leyes y además participa en la designación del órgano capaz de "legislar negativamenten. En ambos casos, las decisiones de estos gobernantes pueden hacer perder eficacia a una norma legal.

Naturalmente, la coincidencia no tiene por qué ser perfecta: del mismo modo que no toda la materia constitucional está siempre recogida en la Constitución formal ni todo lo que aparece en la Constitución formal es materia constitucional, puede suceder que la Constitución determine el procedimiento de designación de un gobernante de segundo nivel o que deje a las leyes la determinación del procedimiento para la designación de otros que sean verdaderamente gobernantes superiores.

No es una casualidad que en numerosos paises se encomiende, a veces en exclusividad, al Tribunal Constitucional la función específica de garantizar el respeto de los preceptos constitucionales y legales que regulan la designación de algunos de los gobernantes superiores del Estado ${ }^{93}$. Aquí, como sabemos, no se regula como función especi-

93 Así, en Francia, la designación del Presidente de la República y como alto tribunal electoral, tanto en la elección de diputados y senadores como en la verificación de todas las operaciones de los referenda (arts. 58 a 60 Constitución de 1958 y arts. 30 a 51 de la Ley Orgánica del Consejo Constitucional). En Grecia, como Tribunal electoral de forma semejante a Francia, pero además en causas de incompatibilidades o privación del mandato a un diputado (art. 100 de la Constitución de 1975). En Italia, de enjuiciamiento del Presidente de la República que puede dar lugar a su destitución (arts. 134 y 90 de la Constitución de 1947). En Portugal, se reserva al Tribunal Constitucional la verificación de todos los actos que pueden poner fin al mandato del Presidente de la República, los actos del procedimiento electoral y de los referenda (art. 225 de la Constitución de 1976). En Alemania, algo seme- 
fica y expresa, salvo en el caso del nombramiento de los propios magistrados del Tribunal Constitucional (arts. 2.1.g. y 10.f. LOTC). Considerar pues que la expresión "actos con fuerza de ley" engloba los demás actos de designación de los gobernantes supremos del Estado no sería sino reconocer a nuestro Tribunal Constitucional una función que vienen ejerciendo otros, al menos respecto de algunos de tales gobernantes.

Por otra parte, cuando la LOTC habla de actos con fuerza de ley da por sentado que no sólo los órganos estatales sino los autonómicos pueden dictarlos (arts 2.1.a. y concordantes de la LOTC) Ahora bien ¿qué actos con fuerza de ley cabe suponer sean dictados por tales órganos? Si examinamos la amplia lista de casos que hemos ido proponiendo observaremos que únicamente el nombramiento de Presidente de la Comunidad (propiamente la propuesta, pues el nombramiento mismo es un acto regio) y el decreto de disolución de la Asamblea autonómica pueden considerarse como actos constitucionales con fuerza de ley. Por tanto, si la LOTC da por sentado que existen actos con fuerza de ley de las Comunidades autónomas y los únicos posibles son actos constitucionales de personas, habrá que concluir que tales actos son para la LOTC actos con fuerza de ley.

En cualquier caso; sobre los nombramientos de los gobernantes supremos del Estado cuyo procedimiento está casi siempre regulado en la Constitución formal no cabe, propiamente hablando mas que un juicio de constitucionalidad, no de legalidad. ¿sería coherente que fueran los tribunales ordinarios quienes lo realizasen? ¿Lo sería, igualmente, que fueran las Salas del Tribunal Constitucional quienes, es de suponer en vía de amparo, pudiesen anular tales nombramientos? ¿Acaso no es más conforme con la lógica del sistema que sólo el Tribunal Constitucional en Pleno pudiera declarar nulo por inconstitucional el acto de designación de un gobernante supremo del Estado?

A la misma conclusión se llega si nos atenemos a los sujetos legitimados para impugnar: una cuestión tan grave para el interés obje-

jante a lo que sucede en Italia respecto al Jefe del Estado Lart. 61 de la Ley Fundamental de Bonn) y también como alto tribunal electoral en todo lo referente a la pérdida o adquisición de la condición de diputado federal (art. 41.2 LFB). Fuera de Europa, las atribuciones a los Tribunales Constitucionales, especialmente en las más recientes Constituciones, son a veces más amplias: en Chile, no sólo la designación y cesación de parlamentarios, sino de ministros; en Ecuador, todos los que aquí llamamos actos constitucionales pueden ser enjuiciados por el Tribunal Constitucional, en la Federación Rusa y en la República de Lituania todo lo relativo a cesación del Presidente, etc. 
tivo como es la determinación de las personas que integran o presiden los órganos constitucionales no puede ser objeto de impugnación por parte de cualquier sujeto particular que considere violados sus derechos fundamentales. La propia naturaleza de las decisiones políticas que se formalizan en cualquier acto constitucional aconseja reducir la legitimación para impugnarlos a los sujetos políticos fundamentales, es decir, a quienes pueden interponer el recurso de inconstitucionalidad contra las leyes, dado que lo que se debe defender aqui es el interés general más que la protección de derechos individuales que pudieran resultar lesionados por un acto constitucional ${ }^{94}$.

Una razón más para considerar que los actos constitucionales son actos con fuerza de ley estriba en las vías para su control ante el Tribunal Constitucional. Como vimos más arriba, si los actos constitucionales tienen fuerza de ley pueden dar lugar a un recurso de inconstitucionalidad en el que cualquier infracción de la Constitución puede fundamentar una sentencia de nulidad del acto recurrido. En cambio, si los actos constitucionales no tienen fuerza de ley, ninguna de las tres vías posibles garantiza el pleno control de constitucionalidad:

a) En el recurso de amparo sólo pueden alegarse (y ser tenidas en cuenta por el Tribunal Constitucional) las infracciones del Ordenamiento que supongan violación de cualquier derecho fundamental, no las demás infracciones de la Constitución o del bloque de constitucionalidad ${ }^{95}$. Sólo una extensión abusiva del contenido de los derechos de los arts. 14 y sobre todo 23 CE permitiría considerar lesionados los derechos fundamentales de quienes no fueron nombrados para un cargo

94 "No se defiende mediante este recurso [de inconstitucionalidad] ningún interés o derecho propio sino el interés general y la supremacía de la Constitución, de manera que el ius agendi en que tal facultad consiste [la interposición de dicho recurso] sin conexión alguna con los derechos de que es titular la persona que lo ejerce, forma parte de las competencias que corresponden al órgano que se ocupa o del haz de facultades propias de la representación politica que se ostentan STC 42/1985, FJ $22^{\circ}$.

${ }_{95}$ El propio Tribunal Constitucional ha considerado a las resoluciones del Presidente del Congreso que completan lagunas del reglamento parlamentario, to integran o lo aclaran como "normas con fuerza de ley" por entender que "la inclusión de este tipo de normas dentro del ámbito del recurso de inconstitucionalidad es la única via para permitir el que las mismas puedan ser objeto de control por este Tribunal en razón de cualquier infracción constitucional, y no sólo por la violación de derechos fundamentales de los recurrentes en amparo. Una interpretación pro actione y para evitar la creación de ámbitos normativos exentos de cualquier tipo de control ha llevado a este Tribunal a un análisis sistemático ... que ha permitido una interpretación extensiva de este art. 27.2.d." para incluir en él tales resoluciones: STC 118/1988, FJ 4. . 
constitucional al que aspiraban porque la designación no respetó las mayorías, los procedimientos o los requisitos mínimos objetivos del candidato nombrado, por ejemplo. En otros actos constitucionales resulta muy difícil alegar la lesión de derecho fundamental alguno. Piénsese, por ejemplo, en la convalidación o no de los decretos-leyes, y en la autorización o no para ratificar un tratado internacional.

b) En los conflictos de competencias difícilmente podrá cuestionarse la titularidad de la competencia ejercida cuando hablamos de actos constitucionales, y aun en los escasos supuestos en que así sea (nombramiento de Presidente de la Comunidad Autónoma por la cuestión del refrendo, por ejemplo, STC 5/1987) tampoco puede alegarse cualquier infracción de la Constitución, sino exclusivamente del orden de competencias establecido en ella y en los Estatutos de autonomía (arts. 62 y ss LOTC).

c) En las impugnaciones del art. 161.2 CE sólo aquellos escasos actos constitucionales que proceden de las Comunidades autónomas podrían ser controlados, pero no los actos regios o de las Cámaras nacionales que son casi todos.

En definitiva, si consideramos a los actos constitucionales como actos con fuerza de ley podrán ser impugnados ante el Pleno del Tribunal Constitucional por la vía del recurso o, cuando sea posible, de la cuestión de inconstitucionalidad y entonces podrá alegarse cualquier infracción de la Constitución o, en su caso, de las normas legales que rigen la emisión del acto. Si, por el contrario les negamos tal categoría, entonces los actos constitucionales formalizados por real decreto serían fiscalizables por la Sala 3. ${ }^{a}$ del Tribunal Supremo, que deberá realizar un juicio de constitucionalidad, y los parlamentarios única y directamente por las Salas del Tribunal Constitucional en vía de amparo, pero entonces el único parámetro por el que pueden ser fiscalizados es el de los derechos fundamentales de los arts. 14 a 29 y 30.2 CE.

\section{CONCLUSIONES}

Primera: existe en nuestro Ordenamiento una categoría de actos juridico-públicos que no son normas ni tampoco actos administrativos, sino actos singulares y concretos a los que, por encontrarse directamente incardinados en la Norma constitucional damos la denominación de «actos constitucionales». Pese a la gran variedad y las importantes diferencias entre unos $y$ otros de tales actos es posible construir una categoría dogmática unitaria que los englobe a todos. 
Segunda: tales actos son casi siempre o actos regios o actos parlamentarios. A nivel autonómico existen también algunos escasos actos constitucionales, o de la Asamblea o del Presidente de la Comunidad. Los actos formalmente regios son sin embargo decididos por otros órganos constitucionales (las Cámaras, el Gobierno o su Presidente, el Consejo General del Poder Judicial, el Tribunal Constitucional o las Asambleas autonómicas).

Tercera: podemos clasificar los actos constitucionales en tres tipos: los encaminados a determinar las personas concretas que han de ocupar los cargos supremos del Estado, los que excepcionan temporalmente preceptos constitucionales, bien sobre estatuto de las libertades, bien sobre distribución territorial del poder, y aquellos actos parlamentarios de convalidación o autorización de normas con rango de ley.

Cuarta: todos los actos constitucionales son actos con fuerza de ley, en el sentido que tal expresión tiene en la LOTC y no existen otros actos con fuerza de ley más que los actos constitucionales. Ello se debe a que la expresión "fuerza de ley" aplicada a los actos en vez de a las normas no conserva hoy en nuestro Ordenamiento su significación original; por el contrario, tiene un significado devaluado, prácticamente como sinónimo de rango y valor de ley, pero normalmente ya no tiene necesariamente que ver con la "fuerza activa" ni "fuerza pasiva" del acto. La expresión "actos con fuerza de ley» no es sino un artificio procesal creado por la LOTC para evitar que ciertas decisiones singulares vitales quedaran exentas de control por el Tribunal Constitucional.

Quinta: como consecuencia, los actos constitucionales son inmunes, igual que las leyes y normas con rango de ley, a cualquier control por el poder judicial. Sólo el Pleno del Tribunal Constitucional por la vía del recurso de inconstitucionalidad y cuando sea posible por la vía de la cuestión, puede decidir si fueron dictados respetando las normas constitucionales y eventualmente legales que regulan la emisión de tales actos.

Sexta: la nueva LJCA no sólo no ha eliminado las graves deficiencias del sistema hasta ahora vigente de fiscalización de los actos constitucionales, sino que, por el contrario, ha venido a introducir mayor confusión e incoherencia en él: los actos constitucionales que se formalicen como reales decretos podrán ser objeto de impugnación

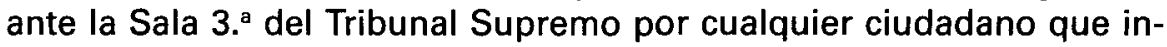
voque un interés legítimo. Queda esperar que la jurisprudencia vaya excluyendo al menos los actos regios dictados a propuesta de órganos constitucionales distintos del propio Gobierno. 